Citation: R. Palumbo, A. Gonçalves, A. Gkrillas, A. Logrieco, J.-L. Dorne, C. Dall'Asta, A. Venâncio, P. Battilani (2020) Mycotoxins in maize: mitigation actions, with a chain management approach. Phytopathologia Mediterranea 59(1): 5-28. doi: 10.14601/Phyto-11142

Accepted: November 8, 2019

Published: April 30, 2020

Copyright: (c) 2020 R. Palumbo, A. Gonçalves, A. Gkrillas, A. Logrieco, J.-L. Dorne, C. Dall'Asta, A. Venâncio, P. Battilani. This is an open access, peer-reviewed article published by Firenze University Press (http://www. fupress.com/pm) and distributed under the terms of the Creative Commons Attribution License, which permits unrestricted use, distribution, and reproduction in any medium, provided the original author and source are credited.

Data Availability Statement: All relevant data are within the paper and its Supporting Information files.

Competing Interests: The Author(s) declare(s) no conflict of interest.

Editor: Dimitrios I. Tsitsigiannis, Agricultural University of Athens, Greece.
Review

\section{Mycotoxins in maize: mitigation actions, with a chain management approach}

\author{
Roberta PALUMBO ${ }^{1}$, Ana GONÇALVES ${ }^{2}$, Athanasios GKRILlaS ${ }^{3}$, \\ Antonio LOGRIECO ${ }^{4}$, JeAn-Lou DORNE ${ }^{5}$, Chiara DALl'ASTA ${ }^{3}$, Arman- \\ Do VENÂNCIO ${ }^{2}$, PAOLA BATTILANI ${ }^{1}$ \\ ${ }^{1}$ Faculty of Agriculture, Università Cattolica del Sacro Cuore, Via Emilia Parmense 84, \\ 29100 Piacenza, Italy \\ ${ }^{2}$ CEB - Centre of Biological Engineering, University of Minho, 4710-057 Braga, Portugal \\ ${ }^{3}$ Università degli studi di Parma, Via Università 12, 43121, Parma, Italy \\ ${ }^{4}$ National Research Council, Institute of Sciences of Food Production, via Amendola \\ 122/O, 70126, Bari, Italy \\ ${ }^{5}$ European Food Safety Authority (EFSA), Via Carlo Magno 1A, 43126, Parma, Italy \\ ${ }^{\star}$ Corresponding author: paola.battilani@unicatt.it
}

Summary. Maize is the principal staple food/feed crop exposed to mycotoxins, and the co-occurrence of multiple mycotoxins and their metabolites has been well documented. This review presents the infection cycle, ecology, and plant-pathogen interactions of Aspergillus and Fusarium species in maize, and current knowledge on maize chain management to mitigate the occurrence of aflatoxins and fumonisins. Preventive actions include at pre-harvest, as part of cropping systems, at harvest, and at postharvest, through storage, processing, and detoxification to minimize consumer exposure. Preventive actions in the field have been recognized as efficient for reducing the entrance of mycotoxins into production chains. Biological control of Aspergillus flavus has been recognized to minimize contamination with aflatoxins. Post-harvest maize grain management is also crucial to complete preventive actions, and has been made mandatory in government food and feed legislation.

Keywords. Aspergillus, Fusarium, aflatoxins, fumonisins, deoxynivalenol.

\title{
INTRODUCTION
}

Maize is one of the most important cereals produced for human and animal consumption in the European Union (EU), and is grown mainly for grain and forage. More than $80 \%$ of maize grain is used for feed, and the rest is used for production of starch and semolina (Eurostat, 2019). In 2017/2018, the EU maize yields reached approx. 65 million tons (European Commission, 2019), approx. 5\% of the global maize production. Maize is second to wheat in total EU cereal production (Statista, 2018). Since 2017, the EU has been importing significant volumes of maize, mainly coming from Ukraine, Brazil, and Canada. This is partly due to the increased demand for maize feed $(+8 \%)$, and significant reductions in the production of barley and other cere- 
als for feed consumption (European Commission, 2019). As well, there has been significant reduction in maize growing areas in some European countries, where mycotoxin contamination is a major concern. That is because of the economic losses caused by discarded lots that are non-compliant with legal mycotoxin limits, and the consequent income uncertainty for farmers.

Maize is exposed to mycotoxins, which are secondary metabolites of fungi with toxic effects on humans and animals, and which cause illnesses and also economic losses. Mycotoxin contamination is the major non-tariff trade barrier for agricultural products, which negatively impacts the health and income of small-holder farmers, regional and international trade, and the world economy (Logrieco et al., 2018). A range of toxic effects has been associated with exposure to mycotoxins in humans and in many animal species (Eskola et al., 2018). Hence, the maximum concentrations of the main class of mycotoxins in agricultural food and feed products, as well as in their commodities, are regulated in Europe, or recommendations are listed for animal consumption (Commission Regulation (EU) 576/2006; Commission Regulation (EU) 1881/2006; Commission Regulation (EU) 574/2011; Commission Recommendations (EU) 165/2013).

One of the major issues in the contamination of maize is infection with Aspergillus flavus and Aspergillus parasiticus, and the resulting occurrence of aflatoxins (AFs). In addition, the occurrence of aflatoxin B1 (AFB1) in feed can lead to contaminated milk, because the toxin is metabolized to aflatoxin M1 (AFM1) by dairy cattle when fed with contaminated feed, and there is carryover to dairy products (EFSA, 2004; van der Fels-Klerx and Camenzuli, 2016).

Fusarium species also infect maize and contaminate grains with mycotoxins, which include deoxynivalenol (DON), zearalenone (ZEN), fumonisins (FBs), nivalenol (NIV), T-2 toxin (T2), and HT-2 toxin (HT2). In maize the co-occurrence of AFs and FBs is common (Camardo Leggieri et al., 2015). Although there are no data demonstrating significant interaction between these toxins, reports suggest that both additive and synergistic interactions may occur (Torres et al., 2015; Abbès et al., 2016; Qian et al., 2016). Mycotoxins are very stable compounds and accumulate in maize grain in the field after fungal infections during the crop growing season, with possible post-harvest increases when the environment remains suitable for fungal activity. Main factors affecting maize infection are: environmental conditions, plant susceptibility (depending on crop genetics and health status) as well as insect populations.

Many efforts have been devoted to develop strategies, both at the pre- and post-harvest crop stages, to reduce production and occurrence of these mycotoxins in maize, and their entry into the food and feed chains. The present provides an account of advances since 2000 in strategies to reduce the occurrence of AFs, FBs, and DON across the maize supply chain.

\section{ASPERGILLUS AND FUSARIUM SPECIES IN MAIZE}

Many of the most relevant mycotoxins in maize are synthesized by two fungal genera: Aspergillus and Fusarium. Aspergillus spp. include all validated AFproducing fungi and most of the known species belong to the Aspergillus section Flavi, including A. flavus and its close relative A. parasiticus. Aspergillus flavus and A. parasiticus are very similar species of the section, sharing 96\% DNA similarity of the aflatoxin gene clusters (Cary and Ehrlich, 2006). These species can be distinguished from one another using morphological and physiological characteristics, but A. flavus commonly only produces $B$ series AFs, while $A$. parasiticus can produce both B and G series AFs. Non-aflatoxigenic strains also naturally occur in both species (Smith and Moss, 1985). Aspergillus flavus almost exclusively occurs in maize (Giorni et al., 2007).

The most frequently isolated Fusarium species from maize are F. verticillioides, $F$. proliferatum, F. graminearum, and F. subglutinans (Leslie and Logrieco, 2014). These cause two different types of ear rot: (i) Fusarium ear rot or pink ear rot is caused primarily by members of the Liseola section, including F. verticillioides, F. proliferatum and $F$. subglutinans, now preferably referred to as the Gibberella fujikuroi species complex (GFsc); and (ii) Gibberella ear rot or red ear rot which is caused by species of the Discolor section, with F. graminearum being the prevalent species. Fusarium verticillioides and F. proliferatum can synthesize large amounts of FBs. Other species can be involved in the pathogenesis of maize ear rot, including F. culmorum and $F$. equiseti (Logrieco et al., 2002). These two fungi produce trichothecenes (DON and NIV) and ZEN. Studies reporting the presence of $F$. sporotrichioides and $F$. langhsethiae in maize are scarce (Görtz et al., 2008), but these two species have been shown to produce T2 and HT2, and their roles in maize contamination with these two mycotoxins needs to be clarified. Recently, a new mycotoxin-producing species of Fusarium, F. temperatum, has been reported in Europe and South America by different authors. This species is morphologically similar and phylogenetically close to $F$. subglutinans, and has been reported as a producer of FBs, beauvericin (BEA), fusaproliferin (FUS) and moniliformin (MON) (Scauflaire et al., 2012; Fumero et al., 2016). 
Infection cycle of Aspergillus and Fusarium species on maize

Maize is susceptible to mycotoxin-producing fungi from flowering, at growth stage $\mathrm{BBCH} 63$ (male: beginning of pollen-shedding; female: when tips of stigmata are visible), and fungus infection efficacy is optimized at BBCH67 (female: stigmata drying) (Battilani et al., 2003; Battilani et al., 2013). Aspergillus and Fusarium species commonly reproduce by asexual spores (Battilani et al., 2013). The conidia of Aspergillus are dispersed mainly by air movement (Battilani et al., 2003). Fusarium species produce macroconidia which, for $F$. graminearum, are typically dispersed by splashing rain, and for the GFsc, also by air movement (Shaner, 2003; Paul et al., 2004; Manstretta and Rossi, 2015; Manstretta and Rossi, 2016). Conidia in crop debris are considered the main sources of infection, and they enter host plants through natural openings or wounds (Cotten and Munkvold, 1998). Sexual reproduction is possible for Fusaria, and the relevance of this depends on the species and the crop location, while for A. flavus sexual reproduction has been demonstrated in the laboratory, and some evidence suggests that it could occur in nature although not yet observed (Horn et al., 2009; Horn et al., 2016).

Systemic development of Fusarium species from maize seeds and roots to the stalks and to cobs can also contribute to kernel infection, but the role of systemic infections remains to be confirmed (Munkvold et al., 1997; Murillo-Williams and Munkvold, 2008). Systemic infection by Aspergillus has never been considered.

Beside silk and systemic infection, insect-assisted infections by mycotoxigenic fungi have also been identified as important pathway for maize ear infections by Aspergillus and Fusarium species. Insects can be vectors of inoculum and host entry can be assisted by larvae feeding on kernels (Munkvold and Carlton, 1997). Lepidoptera typically have the greatest impacts on mycotoxin-producing fungi in maize. Much attention has been given to the interactions between Lepidoptera, including the European corn borer (ECB; Ostrinia nubilalis), and F. verticillioides infections (Blandino et al., 2015; Drakulic et al., 2017). ECB is the main maize pest in Central and Southern Europe, and this insect has been shown to promote $F$. verticillioides and $F$. proliferatum infections in maize grains and consequent FB contamination, in temperate areas (Blandino et al., 2015). The incidence of the western flower thrips (Frankliniella occidentalis) on maize ears has also been correlated with the presence of $F$. verticillioides (Parsons and Munkvold, 2012). Further evidence also indicates that kernel injury attributed to the western bean cutworm (WBC; Striocosta albicosta) can lead to increased levels of $F$. verticillioides and subsequent increased levels of FBs in maize (Parker et al., 2017).

\section{Ecology}

Every fungal species has unique ecological requirements, and optimum conditions for fungal growth are not always those that are most appropriate to mycotoxin biosynthesis (Figures 1 and 2). Therefore, it is difficult to identify common ecological trends across different fungal species. Nevertheless, A. flavus is well adapted to warm and dry weather conditions (Giorni et al., 2016). In contrast, the optimum conditions for the development of $F$. verticillioides include warm temperature $(\mathrm{T})$ and moderate rainfall. Mild $\mathrm{T}$ and high rainfall during maize grain maturation are best for infections by $F$. graminearum (Bhatnagar et al., 2014). T, relative humid-

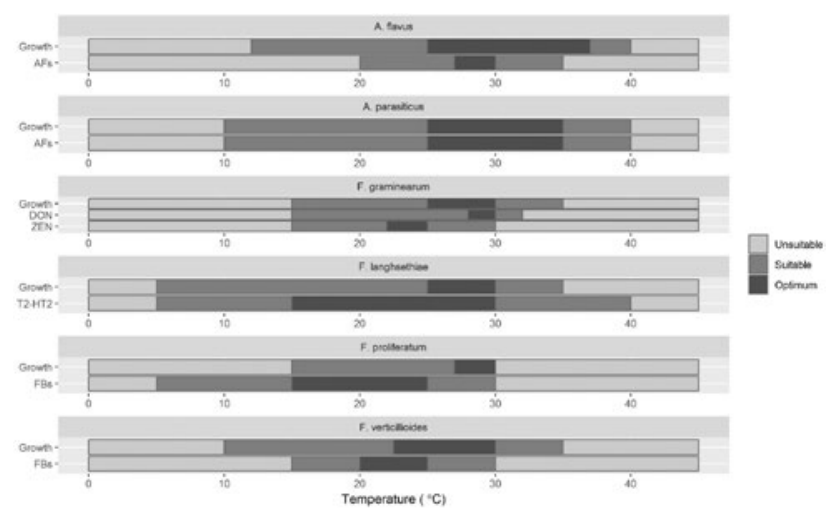

Figure 1. Temperatures $\left({ }^{\circ} \mathrm{C}\right)$ required for fungal growth and mycotoxin production for Aspergillus and Fusarium species isolated from maize.

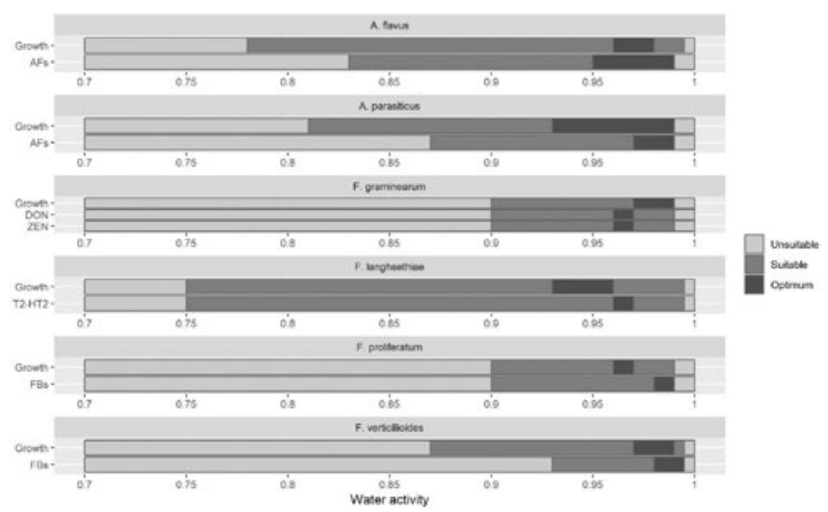

Figure 2. Water activity $\left(\mathrm{a}_{\mathrm{w}}\right)$ required for fungal growth and mycotoxin production for same of the most relevant Aspergillus and Fusarium species isolated from maize. 
ity $(\mathrm{RH})$, and, above all, grain water activity $\left(\mathrm{a}_{\mathrm{w}}\right)$ are the most important ecological factors influencing fungal colonization of maize grain substrates (Giorni et al., 2011; Lazzaro et al., 2012; Battilani et al., 2016).

In vitro trials have indicated that the optimum $\mathrm{a}_{\mathrm{w}}$ for growth of $A$. flavus is in the range of 0.96 to 0.98 at $25^{\circ} \mathrm{C}, 0.98$ at $30^{\circ} \mathrm{C}$, and 0.96 at $37^{\circ} \mathrm{C}$ (Pitt and Miscamble, 1995). In the field, A. flavus can grow in maize grain at $\mathrm{a}_{\mathrm{w}}$ as low as 0.73 (8-12\% moisture content), and produce AFs down at $\mathrm{a}_{\mathrm{w}}=0.85$ (17-19\% moisture) (Giorni et al., 2011; Battilani et al., 2013; Battilani et al., 2016). In vivo trials also shown that $\mathrm{AFB} 1$ is positively correlated with $\mathrm{a}_{\mathrm{w}}$ when $\mathrm{a}_{\mathrm{w}} \geq 0.95$, confirming the in vitro data, and is negatively correlated when $\mathrm{a}_{\mathrm{w}}<0.95$ (Giorni et al., 2016). Therefore, $a_{w}$ of 0.95 is proposed as a threshold, at which AF production increases rapidly. The influence of abiotic stresses on A. flavus infection is complicated by the co-existence of different fungal species in maize kernels during the crop growing season. Previous in vitro studies considered the competition between $F$. verticillioides and A. flavus (Giorni et al., 2014). Dominance of one species over the other was demonstrated only under extreme conditions, while mutual antagonism was more common (Giorni et al., 2016).

Growth of $F$. verticillioides occurs within a wide range of $\mathrm{T}$, with an optimum $\mathrm{T}$ range of 22.5 to $27.5^{\circ} \mathrm{C}$ and a minimum $\mathrm{a}_{\mathrm{w}}=0.87$. The optimum $\mathrm{T}$ and $\mathrm{a}_{\mathrm{w}}$ reported for inducing FB production are from 20 to $25^{\circ} \mathrm{C}$ and 0.95 to $0.99 \mathrm{a}_{\mathrm{w}}$, while no production was observed at $10^{\circ} \mathrm{C}$ and $\mathrm{a}_{\mathrm{w}} \leq 0.93$ (Medina et al., 2013). Fusarium temperatum strains reached maximum growth rate at $\mathrm{T}$ values greater than $22^{\circ} \mathrm{C}$ and the least growth was at $15^{\circ} \mathrm{C}$ and $0.95 \mathrm{a}_{\mathrm{w}}$, and these strains produced maximum amounts $\left(1000 \mu \mathrm{g} \mathrm{g}^{-1}\right)$ of fumonisin B1 (FB1) at $0.98 \mathrm{a}_{\mathrm{w}}$ and $15^{\circ} \mathrm{C}$ (Fumero et al., 2016). Fusarium graminearum grew over a wide range of $\mathrm{T}$ and moisture conditions, with the optimum growth at approx. $25^{\circ} \mathrm{C}$ and $\mathrm{a}_{\mathrm{w}}=0.977-0.995$. The influence of incubation $\mathrm{T}(15$, 20,28 , or $\left.32^{\circ} \mathrm{C}\right)$ and $\mathrm{a}_{\mathrm{w}}(0.96,0.97$, or 0.98$)$ on the production on DON by F. graminearum on maize kernels was studied by Llorens et al. (2004). They demonstrated that $\mathrm{a}_{\mathrm{w}}$ in the range considered did not significantly affect trichothecene synthesis, while $\mathrm{T}$ affected DON production with the optimum $\mathrm{T}$ being $28^{\circ} \mathrm{C}$.

\section{Plant-pathogen interactions}

Differences in chemical composition of maize kernels during each growing season and related plant physiology, can be variedly associated with fungal colonization and mycotoxin contamination (Luo et al., 2008; Luo et al., 2011).
The dynamics of $a_{w}$ in grains during the growing season determines the competitiveness of $\mathrm{A}$. flavus against other co-occurring ear rot fungi (Giorni et al., 2011). The ability of A. flavus and other ear rot fungi such as $F$. verticillioides to utilize carbon sources at different $\mathrm{T}$ and $\mathrm{a}_{\mathrm{w}}$ conditions could also influence the dynamics of AF contamination (Giorni et al., 2016). Other factors, such as crop growth stage, physiology, active plant defenses, and grain composition, are also likely to influence the dynamics of AF production during grain ripening (Ojiambo et al., 2018). The rate of drying of the ripening kernels critically affects their contamination with AFs and FBs (Medina et al., 2013). The most significant increase in FB production and accumulation occurs after the dent stage. This stage is also characterized by acidification and maximum levels of amylopectin content; both of which enhance FB synthesis (Picot et al., 2011).

Lipid composition of maize kernels also affects fungal infection and toxin accumulation by Aspergillus and Fusarium species (Dall'Asta et al., 2012; Dall'Asta et al., 2015; Battilani et al., 2018). Plant and fungal oxylipins play crucial roles in cross-talk between the pathogens and their host (Scala et al., 2013; Ludovici et al., 2014; Battilani et al., 2018).

\section{OCCURRENCE OF MULTIPLE MYCOTOXINS}

A survey by Streit et al., (2013) indicated that, on a global scale, $84 \%$ of maize was contaminated with at least one mycotoxin, and $46 \%$ was co-contaminated with multiple mycotoxins. The natural co-occurrence of mycotoxins produced by different fungi in maize and maize products has been reported, and most surveys have focused on the major mycotoxins AFs, FBs, ZEN, and trichothecenes (mainly DON) (Smith et al., 2016; Ingenbleek et al., 2019). Only a few studies have specified the percentage of the co-contaminated samples. Common co-occurrence of AFs + FBs, FBs + DON, and FBs + DON + ZEN has been reported (ranging from 25\% to $40 \%)$. More details of the main reported mycotoxin combinations are summarized in Table 1.

Apart from the occurrence of parent forms, modified mycotoxins have been frequently reported to co-occur in cereals, including maize (Rasmussen et al., 2012; Nakagawa et al., 2013; Kovalsky et al., 2016). Glucosides of DON, ZEN, and other minor trichothecenes have been frequently described. Mycotoxin modification in wheat is part of the biotransformation machinery expressed by host plants in response to pathogen attacks (Berthiller et al., 2009a). However, toxin biotransformation has been little investi- 
Table 1. Co-occurrence of mycotoxins in maize and derived products.

\begin{tabular}{|c|c|c|c|}
\hline Mycotoxin & Commodity & Observation & References \\
\hline AFs; FBs & Maize & $95.6 \%$ of samples with $\mathrm{AFB} 1$ and $\mathrm{FBs}(\mathrm{FB} 1+\mathrm{FB} 2)$ & $\begin{array}{l}\text { Camardo Leggieri et al. } \\
\text { (2015) }\end{array}$ \\
\hline \multirow[t]{3}{*}{ FBs; DON } & Maize products & $\begin{array}{l}\text { High co-occurrence of } \mathrm{fb} 1, \mathrm{fb} 2 \text { and don strong evidence of } \\
\text { co-occurrence of } \mathrm{fb} 1 \text { and } \mathrm{fb} 2\end{array}$ & Cano-Sancho et al. (2012) \\
\hline & $\begin{array}{l}\text { Maize and maize } \\
\text { products }\end{array}$ & $38 \%$ of samples with fbs and don & Kirincic et al. (2015) \\
\hline & Maize & $25 \%$ of samples with don $+\mathrm{fb} 1$ & Zachariasova et al. (2014) \\
\hline FBs; BEA & Maize & $\begin{array}{l}97 \% \text { of samples with } \mathrm{fb} 1 \text { and } \mathrm{fb} 2 \\
10 \% \text { of samples with ota } \\
17 \% \text { of samples with bea } \\
15 \% \text { of samples with bea, } \mathrm{fb} 1 \text { and } \mathrm{fb} 2 \\
3 \% \text { of samples with bea and ota }\end{array}$ & Jurjevic et al. (2002) \\
\hline FBs; ZEN & Maize & $40 \%$ of samples with fbl and zen & Domijan et al. (2005) \\
\hline \multirow[t]{2}{*}{ FBs; DON; ZEN; OTA } & $\begin{array}{l}\text { Maize and maize } \\
\text { products }\end{array}$ & $\begin{array}{l}57 \% \text { of samples with co-occurring mycotoxins } \\
38 \% \text { of samples with fbs, don and zen }\end{array}$ & Kirincic et al. (2015) \\
\hline & Maize & $\begin{array}{l}40 \% \text { of samples with fb1, zen and ota } \\
6 \% \text { of samples with } \mathrm{fb} 1, \mathrm{fb} 2 \text { and ota }\end{array}$ & Domijan et al. (2005) \\
\hline \multirow[t]{4}{*}{ DON; DON derivates } & Maize & High occurrence of don and don $3 g$ & $\begin{array}{l}\text { Desmarchelier and } \\
\text { Seefelder (2011) }\end{array}$ \\
\hline & $\begin{array}{l}\text { Maize and maize } \\
\text { products }\end{array}$ & High co-occurrence of don, 3-adon, 15-adon and don3g & De Boevre et al. (2012) \\
\hline & Maize & Consistent co-occurrence of don and don3g in all tested samples & Berthiller et al. (2009b) \\
\hline & Maize & $50 \%$ of sample with don + its acetylated and/or glycosylated derivates & Zachariasova et al.(2014) \\
\hline DON; BEA & Maize & $38 \%$ of sample with don and bea & Zachariasova et al. (2014) \\
\hline \multirow[t]{2}{*}{ DON; ZEN } & $\begin{array}{l}\text { Maize and maize } \\
\text { products }\end{array}$ & $25 \%$ of samples with don and zen & Kirincic et al. (2015) \\
\hline & Maize & $26 \%$ of sample with don and zen & Zachariasova et al. (2014) \\
\hline DON; T2-HT2 & $\begin{array}{l}\text { Maize and maize } \\
\text { products }\end{array}$ & High co-occurrence of don and ht2 & Cano-Sancho et al.(2012) \\
\hline DON;NIV; T2-HT2 & Maize & Relatively high content of niv, higher than for don for same samples & Rasmussen et al. (2012) \\
\hline
\end{tabular}

gated in maize. Occurrence of modified FBs in maize has been reported (Bryła et al., 2013a; Dall'Asta and Battilani, 2016), and conjugation of FBs with fatty acids (oleic and linoleic acids) through the formation of ester bonds has been described (Bartók et al., 2010; Bartók et al., 2013; Falavigna et al., 2016). Recent evidence strongly supports the hypothesis that fatty acid esters of FB1 are produced by $F$. verticillioides using fatty acids from the substrate (Falavigna et al., 2016). These compounds are formed by the fungus in a substrate concentration-dependent manner (Falavigna et al., 2016), and they may undergo cleavage in the gastrointestinal tracts of mammals.

FBs can also occur as non-covalently bound forms, also known as "hidden fumonisins", now referred to as modified mycotoxins (Rychlik et al., 2014). Several studies have demonstrated the complexation of FBs with maize macro-constituents, the main one being starch (Dall'Asta et al., 2009; Dall'Asta et al., 2010; Dall'Asta et al., 2012; Bryła et al., 2015). This complexity may significantly affect the quantification of FBs under routine conditions, requiring additional hydrolysis steps under alkaline conditions. The amounts of modified FBs are closely related to environmental factors and chemical composition of maize, and may significantly contribute to the overall amount of FBs occurring in each sample. The ratio between free and total FBs has been reported at between 0.4 to 0.7 , depending on yearly variations and host hybrid examined (Dall'Asta et al., 2012; Bryła et 
al., 2015; Giorni et al., 2015). Dry milling of maize also increased free FBs in bran by $69 \%$ and total FBs partitioning in fractions by $46 \%$, while free FBs decreased in flour by $28 \%$ and total FBs partitioning in fractions by $20 \%$ (Bryła et al., 2015). Total release of this fraction under digestive conditions has been considered by the European Food Safety Authority. The contribution of modified FBs to overall FB exposure in animals, using an additional factor of 1.6 with respect to the free FB contents has been proposed. This factor has been extrapolated from several studies and a broad database $(\mathrm{n}=$ 316) (Dall'Asta et al., 2010; Dall'Asta et al., 2012; Bryła et al., 2013b; Bryła et al., 2014; Bryła et al., 2015; Oliveira et al., 2015).

In contrast to Fusarium mycotoxins, no modification of AFs in maize has yet been reported.

\section{FIELD PREVENTION STRATEGIES FOR MAIZE MYCOTOXINS}

Several research efforts have defined good agricultural practices (GAPs) to apply during pre-harvest stages, including: (i) farming systems, (ii) host resistance and hybrid selection, (iii) soil management, crop residues and crop rotations, (iv) irrigation, (v) pest and disease control, and (vi) biological control agents (BCAs) (Blandino et al., 2009a; Blandino et al., 2009b; Battilani et al., 2012).

\section{Farming systems}

Little information is available on fungal incidence in organic versus conventional farming of maize. Lazzaro et al. (2015) demonstrated that Fusarium incidence was different between farming systems in Italian maize $(20 \%$ in conventional production and 35\% for organic production). However, Aspergillus incidence was not linked to the farming system but to weather conditions. Mycotoxin occurrence was not considered by Lazzaro et al., (2015).

The most relevant agricultural factors that should be considered essential for integrated programmes to reduce Aspergillus and Fusarium toxins are outlined below, and are summarized in Supplementary Table S1.

\section{Host resistance and hybrid selection}

Comprehensive knowledge of plant defense mechanisms may help to identify kernel resistance mechanisms, and assist the development of targeted and inno- vative approaches for breeding resistant crops (Alberts et al., 2016). Plant breeding has been used as a tool to develop maize varieties resistant to abiotic and biotic stresses (Cary et al., 2011; Lanubile et al., 2011; Brown et al., 2013; Farfan et al., 2015; Lanubile et al., 2017). These efforts have resulted in a number of germplasm releases. However, no maize hybrids were found to be completely resistant to fungal infection and/or mycotoxin contamination, because of the need to select for multiple traits and associated genes that contribute collectively to plant resistance. Resistance mechanisms are interconnected processes involving many gene products and transcriptional regulators, as well as host interactions with environmental factors, particularly, drought stress and high T (Jiang et al., 2011). The molecular mechanisms underlying maize resistance have yet to be determined. Research has been devoted to understanding kernel resistant mechanisms at the transcriptional level, and to identify stress and/or defense related genes induced during A. flavus infection in maize (Chen, et al., 2001; Chen et al., 2015). Microarray or proteomic studies have led to the discovery of many genes involved in maize resistance including several resistance-related quantitative trait loci (QTLs) (Kelley et al., 2012; Brown et al., 2013). Comparisons between the resistant and susceptible lines indicate differences in gene expression networks (Luo et al., 2011). Several research outputs are available on plantpathogen interactions and host resistance; these are promising starting points for future developments, but clear suggestions regarding hybrid selection, considered the best prevention tool, is not feasible.

\section{Soil management, crop residues and crop rotation}

Crop rotation and tillage are recommended practices to reduce inoculum of fungi on overwintering crop residues. Studies on the effects of these practices in maize show variable results, depending on the nature of the pathogen, the geographical location and the combinations with other strategies (Leslie and Logrieco, 2014). Under conditions of high $\mathrm{T}$ and low $\mathrm{a}_{\mathrm{w}}$, A. flavus becomes the dominant fungal species in the soil and produces abundant inoculum (Horn, 2003). Fusarium inoculum is always copious in crop residue in soil, irrespective of environmental conditions. Therefore, soil tillage is commonly considered to reduce inoculum availability. The effects of crop rotation are likely to be negligible, however, in areas with high prevalence of maize, because of long-distance air dispersal of A. flavus and GFsc (Munkvold, 2014).

Baliukoniene et al., (2011) demonstrated that F. verticillioides, F. proliferatum and F. subglutinans survive 
for at least $630 \mathrm{~d}$ in maize stalk residues left on the soil surface or buried up to $30 \mathrm{~cm}$ deep. Under conventional tillage, the soil was contaminated with $7.0 \pm 0.5$ $\log _{10}$ CFU g-1 of fungal spores belonging to 17 genera of fungi. They identified Fusarium from $80 \%$ soil samples from conventional tillage. In contrast, the soil under notillage was contaminated with $13.5 \pm 12.5 \log _{10} \mathrm{CFU} \mathrm{g}^{-1}$ fungal spores. There is evidence that crop rotation has greater impacts on $F$. graminearum and $F$. culmorum and relative mycotoxins, especially DON and ZEN, rather than FB- and AF-producing fungi (Munkvold, 2014). This is consistent with splash dispersal of their inoculum. Besides affecting fungal population growth, soil conditions also influence plant root development. Crops with poorly developed root systems are more susceptible to water and nutritional stresses, and consequently, are more susceptible to Aspergillus and GFsc infections. Adequate soil drainage to avoid drought stress, especially in clay soils, and adapting tillage strategies to soil conditions (Arino et al., 2009; Blandino et al., 2009a) may reduce fungal activity. Furthermore, crop rotation is applied to control maize pests. This practice is recommended in maize to reduce larval populations of western corn rootworm (Diabrotica virgifera) (Munkvold, 2014).

\section{Irrigation}

Maize has low tolerance to drought-stress, which is considered to be the most crucial factor promoting mycotoxin contamination, in addition to causing significant yield losses. Limited water availability predisposes plants to AF contamination (Battilani et al., 2008; Abbas et al., 2012; Torelli et al., 2012; Damianidis et al., 2018). For A. flavus infection, water stress is particularly critical during silk emergence and kernel ripening, so it is recommended to irrigate according to water needs taking into account also the evapo-transpiration precipitation (water balance). For geographical areas where water can be limiting, maize hybrids tolerant to water stress, in addition to early sowing, should be considered.

Data on FBs are less well defined compared with that for AFs. A field study by Arino et al. (2009) showed that drought stress during early maize reproductive growth was associated with increased risk for grain contamination with $\mathrm{FBs}$ due to $F$. verticillioides. However, the type of irrigation (flood or sprinkler) did not affect FB levels. Although the contribution of water stress to FB contamination is controversial, irrigation according to water needs to avoid drought stress to plants is still recommended, but avoiding excessive and prolonged irrigation close to the stage of milk ripening growth stage is important, as this could enhance FB accumulation
(Blandino et al., 2009a; Munkvold, 2014). Increases of DON concentration of up to 3.5 to 5 -fold, caused by $F$. graminearum, were also documented by Oldenburg and Schittenhelm (2012) in kernels derived from limited watered plots compared to well-watered plots.

\section{Pest and disease control}

Several measures are applied against maize pests, including crop rotation, insecticides, fungicides and other chemical treatments, the use of resistant maize hybrids and biological control agents (BCAs), as well as monitoring and forecasting.

The use of insecticides reduces risk of mycotoxin contamination associated with insects (Folcher et al., 2009). The links between insecticide use (mainly pyrethroids) for the control of ECB and reduction of FB contamination have frequently been described (Blandino et al., 2009a; Blandino et al., 2009b; Blandino et al., 2009c; Folcher et al., 2009; Mazzoni et al., 2011; Folcher et al., 2012). Studies of beneficial effects of combined use of insecticides and fungicides have provided equivocal results. Folcher et al. (2009) demonstrated no synergy between deltamethrin and tebuconazole. Efficacy for reducing FBs was $89.96 \%$ reduction from the insecticide treatment and $89.97 \%$ from insecticide + fungicide. Mazzoni et al., (2011) demonstrated benefit from the combination deltamethrin + tebuconazole in reducing $\mathrm{FB}$ contamination, whereas no modification in $\mathrm{AF}$ content was observed after treatments. Content of FB1 decreased by $35 \%$ in plots treated with tebuconazole and by $56 \%$ with tebucoazole + deltamethrin.

\section{Biological control agents (BCAs)}

Several pre-harvest biological control systems have been developed for maize against Aspergillus spp. and Fusarium spp. These have used a variety of potential biocontrol agents (BCAs), including fungal and bacterial strains or atoxigenic fungal strains, as summarized in Table 2. Many microorganisms have been tested, but only Trichoderma harzianum (Nayaka et al., 2010) and Clonostachys rosea (Luongo et al., 2005; Xue et al., 2014; Samsudin et al., 2017) have been studied under field conditions, and only atoxigenic A. flavus strains have been applied on large scale.

Biological control of pathogenic A. flavus has been based on the use of atoxigenic isolates of this fungus, which act through competitive exclusion of AFproducers in the environment, and during crop tissue infection (Cotty and Bayman, 1993). The efficacy 
Table 2. Current information on reduction of mycotoxin-producing Aspergillus spp. and Fusarium spp., and mycotoxins production by biocontrol microorganisms in vitro, in planta, and in field trials in maize.

\begin{tabular}{|c|c|c|c|}
\hline $\mathrm{BCA}(\mathrm{s})$ & Target fungal species & Type of assay & References \\
\hline \multicolumn{4}{|l|}{ Pre-harvest } \\
\hline Atoxigenic A.flavus strains & A. flavus & In vitro and in field & $\begin{array}{l}\text { Cotty and Bayman (1993); Cotty } \\
\text { (2006); Mauro et al. (2015); } \\
\text { Bandyopadhyay et al.(2016); } \\
\text { Mauro et al. (2018) }\end{array}$ \\
\hline Trichoderma harzianum & A. flavus & In greenhouse and in field & Sivparsad and Laing (2016) \\
\hline Streptomyces spp. & A. flavus & In vitro & Verheecke et al. (2016) \\
\hline Bacillus megaterium & A. flavus & In vitro & Kong et al. (2014) \\
\hline Bacillus subtilis (CW14) & $\begin{array}{l}\text { Aspergillus spp., } \\
\text { Penicillium spp. }\end{array}$ & In vitro & Shi et al. (2014) \\
\hline Saccharomyces cerevisiae & A. parasiticus & In vitro & Armando et al. (2012) \\
\hline $\begin{array}{l}\text { Clonostachys rosea, Gram negative } \\
\text { bacterium (BCA5) }\end{array}$ & F. verticillioides & In vitro & Samsudin et al. (2017) \\
\hline $\begin{array}{l}\text { Atoxigenic } F \text {. equiseti, Clonostachys } \\
\text { rosea, Epicoccum nigrum, Idriella } \\
\text { bolleyi, Trichoderma harzianum, } \\
\text { Trichoderma viride }\end{array}$ & $\begin{array}{l}\text { F. culmorum } \\
\text { F. graminearum } \\
\text { F. proliferatum } \\
\text { F. verticillioides }\end{array}$ & In field & Luongo et al. (2005) \\
\hline Epicoccum nigrum & F. graminearum & In vitro and in planta & Abdallah et al. (2018) \\
\hline Bacillus mojavensis (RRC101) & F. verticillioides & In vitro & Blacutt et al. (2016) \\
\hline $\begin{array}{l}\text { Bacillus spp., Pseudomonas spp. } \\
\text { Paenibacillus spp. }\end{array}$ & F. verticillioides & In planta & Figueroa-López et al. (2016) \\
\hline Trichoderma harzianum & F. verticillioides & In vitro, in greehouse and in field & Nayaka et al. (2010) \\
\hline Clonostachys rosea & F. graminearum & In field & Xue et al. (2014) \\
\hline Trichoderma asperellum & F. graminearum & In vitro and in planta & Yaqian et al. (2016) \\
\hline \multicolumn{4}{|l|}{ Post-harvest } \\
\hline Pichia anomala & A. flavus & In vitro & $\begin{array}{l}\text { Tayel et al. (2013); Hua et al. } \\
\text { (2014) }\end{array}$ \\
\hline Lactobacillus plantarum & A. flavus & In vitro & Ahlberg et al. (2017) \\
\hline Debaryomyces hansenii, BCS003 & $\begin{array}{l}\text { Aspergillus spp., } \\
\text { F. proliferatum, } \\
\text { F. subglutinans }\end{array}$ & In vitro & Medina-Cordova et al. (2016) \\
\hline Lactobacillus plantarum MYS6 & F. proliferatum & In vitro & Deepthi et al. (2016) \\
\hline $\begin{array}{l}\text { Lactobacillus delbrueckii, L. } \\
\text { acidophilus, L. sakei, Pediococcus } \\
\text { acidilactici, Enterococcus faecalis }\end{array}$ & F. proliferatum & In vitro & Khalil et al. (2013) \\
\hline
\end{tabular}

of this technique has been validated for control of AF contamination in maize. Two bio-pesticides with atoxigenic $A$. flavus active ingredients are registered for use on maize crops in the USA (Cotty, 2006), and several are available in the sub-Saharan Africa, grouped under AFLASAFE mark (Bandyopadhyay et al., 2016). Atoxigenic $A$. flavus communities that are endemic to Italy have been identified, and their efficacy for reducing AF contamination by AF-producers has been demonstrated. One strain (MUCL 54911) displayed the greatest effi- cacy against several AF-producers (Mauro et al., 2015), and was selected as the active ingredient in AF-X1, now under consideration for registration in Europe (Mauro et al., 2018). To maximize efficacy for preventing aflatoxin contamination, the product should be adapted to the target crop and environment (Cotty, 2006), and the product should also be applied at the 5th leaf crop growth stage (Mauro et al., 2015).

Far less field-based information is available on the effects of BCAs on FB-producing Fusarium spp. Results 
of bio-assays conducted under controlled conditions have demonstrated moderate suppression of toxigenic F. verticillioides and $F$. proliferatum strains using non-pathogenic Fusarium strains, including F. equiseti (Luongo et al., 2005). Samsudin et al., (2017) studied the effects of two BCAs, a fungus (C. rosea) and a gram-negative bacterium (BCA5), on growth rates of $F$. verticillioides (FV1), the relative expression of the FUM1 gene and FB1 production. The fungal antagonist reduced FB1 contamination on maize cobs by $>70 \%$ at $25^{\circ} \mathrm{C}$, and almost $60 \%$ at $30^{\circ} \mathrm{C}$ regardless of the maize ripening stage. For the bacterial antagonist, however, FB1 levels on maize cobs were significantly decreased only in some temperature/ $\mathrm{a}_{\mathrm{w}}$ treatments $\left(25^{\circ} \mathrm{C}\right.$ and $\mathrm{a}_{\mathrm{w}}=0.976-0.958 ; 30^{\circ} \mathrm{C}$ and $\left.\mathrm{a}_{\mathrm{w}}=0.976\right)$.

Abdallah et al., (2018) demonstrated the capacity of two endophytic fungi (Epicoccum nigrum and Sardoria fimicola) to reduce ZEN amounts in maize under in vitro and in planta conditions. Epicoccum nigrum consistently reduced amounts of DON and 15-ADON. Some microorganisms have also been studied in vitro for their ability to inhibit spoiling Aspergillus spp. and Fusarium spp. species in maize feed and food products, and for use as natural post-harvest preserving agents (Table 2).

\section{GRAIN HARVESTING AND DRYING}

Late harvesting has major impacts on the levels of mycotoxins in maize grain, possibly due to high grain moisture levels and greater periods for fungal growth and toxin production (Munkvold, 2014). Apergillus flavus efficiently produces AFs when maize grain moisture content is less er than $28 \%$. In this context, high $\mathrm{T}\left(>25^{\circ} \mathrm{C}\right)$ and $a_{w}$ less than 0.95 have been suggested as thresholds above which AF accumulates rapidly (Giorni et al., 2016). To reduce AF contamination, therefore, harvesting in hot and dry years should be carried out while avoiding very low moisture contents in maize grain, and limiting the time available for rapid growth of A. flavus and rapid synthesis of AFs. A working compromise for farmers would be to harvest at $22-24 \%$ grain moisture, but not at less than $20 \%$.

Detrimental effects of a late harvesting are also confirmed in Fusarium spp. A study conducted on maize silage in Switzerland demonstrated that samples with high DON contents often came from fields harvested after September (Eckard et al., 2011).

Moisture content of maize grain at harvest is commonly not low enough to guarantee safe storage, so the grain must be dried before storage commences (Bullerman and Bianchini, 2014). Drying is performed using heated air dryers. Many technologies, and different Ts and time combinations, can be applied for artificial drying of cereals. Treatments at $70^{\circ} \mathrm{C}$ for $24 \mathrm{~h}$ have been shown to be the more effective for reducing the incidence and extent of fungal populations, than greater $\mathrm{T}$ and shorter exposure time $\left(95^{\circ} \mathrm{C}\right.$ for $9 \mathrm{~h}$ ) (Giorni et al., 2015). Grain should also be dried to less than $14 \%$ moisture content to be stored safely, with rapid reduction of moisture content during the first $24 \mathrm{~h}$ post-harvest. A final moisture content $<13 \%$ is suggested when A. flavus is present (Channaiah and Maier, 2014).

\section{POST-HARVEST GRAIN MANAGEMENT TO MINIMIZE RISKS OF MYCOTOXIN CONTAMINATION}

\section{Grain cleaning and grading}

Pest attacks, harvesting and subsequent handling of maize grain can generate broken kernels, as well as contamination from soil and foreign materials which may be sources of mycotoxin contamination. Several physical processes are used for automated grain cleaning and grading (e.g. sieving, flotation, density segregation). Maize cleaning is commonly applied to remove powder and small kernel pieces, commonly the portions with the greatest mycotoxin contamination. Grading gained increased interest for improving grain lots to comply with legislated standards for processed products. Originally, grain grading machines were based on particle weight and size and used centrifugation and flotation in air flows. Contemporary grading machines are mainly based on optical sensors. Grading using UV light illumination for AF reduction is widely used, although mycotoxins can accumulate without visible symptoms and so pose limits to the use of optical sorting techniques (Karlovsky et al., 2016).

Studies on the effectiveness of gain cleaning/grading processes have produced equivocal results, possibly due to the different initial levels of contamination of the raw materials tested (Pietri et al., 2009), and because of differences between mycotoxins. Intact kernels were shown to contain approx. 10 times less FBs than broken maize kernels (Murphy et al., 1993), and removal of broken kernels and other impurities from unprocessed maize reduced DON and ZEN by around 70-80 \% (Trenholm et al., 1991). For FB, however, contrasting results have been published. The cleaning step did not affect FB concentration from unprocessed and cleaned maize grain with low contamination (Generotti et al., 2015), while a decrease of $45 \%$ was in medium-high contaminated grain (Fandohan et al., 2005). Removal of fine material (approx. 10\% by weight) in maize grain has been shown to reduce AF levels by $84 \%$ (Hu et al., 2017). 


\section{Grain storage}

After drying and cleaning, maize grain is placed in silos, for short or long periods, where it is prone to toxigenic fungal contamination and subsequent mycotoxin production, if conductive conditions occur. Air temperature, relative humidity and kernel moisture content have been identified as major storage factors influencing fungal activity and grain quality. Moderate T, kernel moisture less than $14 \%$ and dry environment have been demonstrated to limit $A$. flavus growth and subsequent AF contamination in stored maize (Giorni et al., 2008). Monitoring of $\mathrm{T}$ and moisture has been suggested for early detection of fungal growth (Mason and Woloshuk, 2010), and this can be done using manual grain inspection for spoilage by moulds and other quality parameters, and measuring grain T. Both approaches, however, have inherent limitations: human sensory detection could be influenced by subjectivity errors caused by individual biases. Cables used to monitor $\mathrm{T}$ inside bulk grain bins detect changes only when spoiling grain mass is large enough to raise the $\mathrm{T}$, and these changes must happen close to the sensors. Recent studies have examined the use of $\mathrm{CO}_{2}$ production as an early indicator of levels of AFs (Garcia-Cela et al., 2019) or FBs (Mylona et al., 2012) in stored maize, and in other cereals (Mylona et al., 2011; Martín Castaño et al., 2017). These studies have shown $\mathrm{CO}_{2}$ production and trends in the respiration rates, measured by Gas Chromatographic (GC) equipment, can be used as 'storability risk indices' to predict overall quality changes in stored grain.

Hermetic storage in silo bags is an alternative method to mitigate variations of environmental parameters and prevent fungal activity. No variations in AFs, FBs, DON, and OTA or in fungal contamination was observed in silo bags when dynamics of fungi and related mycotoxins were examined during maize storage (Gregori et al., 2013).

Natural compounds with fungicidal or fungistatic activity may be useful for preventing fungal growth in stored maize (Bullerman and Bianchini, 2014; Caceres et al., 2016). Different categories of plant-based compounds with bioactivity against a wide range of fungi have been identified as alternative agents, including antioxidants (Coma et al., 2011; Azaiez et al., 2013; De Lucca et al., 2013; Thippeswamy et al., 2013; Tracz et al., 2016), phenolic compounds (Ferrochio et al., 2013; Thippeswamy et al., 2015), and essential oils (Da Gloria et al., 2010; Matasyoh et al., 2011; Elsamra et al., 2012; Garcia et al., 2012; Koc and Kara, 2014; Sahab et al., 2014; Abhishek et al., 2015; Kalagatur et al., 2015; Liang et al., 2015; Achugbu et al., 2016; Kosegarten et al., 2017; Sawaiet al., 2017) (see Supplementary Table S2). It is difficult to draw general conclusions from available information, due to the diversity of variables considered, including the fungal species and the types of compounds tested. Results have mostly been from small scale experiments, and efficacy in maize storage trials remains to be tested and confirmed. Some general conclusions can be drawn, but results remain to confirmed in practical situations. Most studies have tested effects of particular compounds on fungal growth, whereas few have reported effects on mycotoxin reduction. The reported inhibition rates on AFs (Thippeswamy et al., 2013; Liang et al., 2015; Tracz et al., 2016) and on FBs (Coma et al., 2011; Elsamra et al., 2012; Thippeswamy et al., 2015) ranged from 30 to $100 \%$. Eugenol (4-allyl-2-methoxyphenol) has been frequently reported as the active ingredient in the majority of the tested essential oils (eugenol concentration 34.7$78.4 \%$ ), highlighting the promise for this compound to reduce Aspergilli and Fusaria toxin production (Sahab et al., 2014; Kalagatur et al., 2015; Sawai et al., 2017).

\section{Grain processing}

Food and feed processing can have affect initial content of mycotoxins in raw materials and these processes are here discussed individually.

Milling of maize grain does not destroy mycotoxins, but this process leads to redistribution of mycotoxins among mill fractions. Distribution of Aspergillus and Fusarium toxins in maize products after dry-milling has been investigated in several studies, showing similar patterns of distribution. Mycotoxin contaminations increase, compared to unprocessed maize grain, in bran, germ and fractions intended for animal feed (Coradi et al., 2016), whereas they decrease in flaking grits and flour which are mainly destined to human consumption (Bullerman and Bianchini, 2014; Savi et al., 2016). The distribution of Fusarium toxins (FBs, ZEN and DON) in dry-milled maize products has been assessed, and these results indicate that average mycotoxin content in meals and grits was reduced by $65-88 \%$ compared to the unprocessed grain (Reyneri et al., 2004). A significant decrease (40\%) in FB content from unprocessed maize to cornmeal semolina has also been demonstrated, whereas a significant increase in FB content has been found in middlings, commonly intended for feed production (Generotti et al., 2015). In wet-milling, mycotoxins may be dissolved in the steep water and further redistributed. Forty to $50 \%$ of AFs were moved from corn grain into steep water during wet milling, where $28-38 \%$ of these mycotoxins remained in the fiber fraction, $11-17 \%$ in the gluten fraction, $6-11 \%$ in 
the germ, and only 1\% in starch (Karlovsky et al., 2016; Vanara et al., 2018).

Thermal processing. Most mycotoxins are heat stable, but varying degrees of destruction can be achieved with the application of different time/T combinations. AFs have high decomposition Ts ranging from $237^{\circ} \mathrm{C}$ to $306^{\circ} \mathrm{C}$, but all heat treatments (boiling, roasting, baking or steaming) have been reported to reduce foodstuff contamination (Jalili, 2015). Boiling maize grits reduced AF levels by $28 \%$, while frying the boiled grits gave total reduction of 34-53\% (Bullerman and Bianchini, 2014). Also, FBs are moderately stable compounds in high $\mathrm{T}$, as a significant decrease in these compounds only occurs above $150-200^{\circ} \mathrm{C}$, where thermal processing such as baking, frying, roasting or extruding are applied (Humpf and Voss, 2004; Mohanlall et al., 2013). Bread baking has been shown to reduce concentrations of free FBs by $30-32 \%$ and concentrations of modified FBs by $10-19 \%$. The differences in reduction of modified FBs were explained by the presence of proteins or starch capable of stabilizing the mycotoxins during baking (Bryła et al., 2014). The effects of bread making on DON, T-2 and HT-2 toxin stability in naturally contaminated flour samples have been studied in wheat, but no data are available for maize derived products (Stadler et al., 2018). Increases of DON after bread making have been reported, whereas the conjugated form as glucoside derivative DON3G (deoxynivalenol-3-glucoside) was reduced by approx. 50\% after baking (Monaci et al., 2013). In contrast, only 7.2\% degradation of DON was recorded after baking at $100-$ $250^{\circ} \mathrm{C}$ for $180 \mathrm{~min}$ (Numanoglu et al., 2012).

Decreases in FB contents after thermal processing could be ascribed to the masking phenomena, as well as possible modifications of mycotoxin structure through interactions with other food components leading to the formation of conjugates (Falavigna et al., 2012). Free and total FBs have also been shown to increase after heated drying, especially at $70^{\circ} \mathrm{C}$ for $24 \mathrm{~h}$ exposure. This evidence suggests possible retrogradation of starch, after heating, particularly for amylose, was closely related to modifications in detectable FBs (Giorni et al., 2015).

Flaking and extrusion processes, obtained with high pressure and heating, have been recently reviewed (Jackson et al., 2012; Bullerman and Bianchini, 2014). Several reports showed that FBs decreased after cornflake processing. About 60 to $70 \%$ of the initial amounts of FB1 and FB2 were lost during entire cycle of cornflake processing, with less than $30 \%$ losses occurring during the intermediate extrusion-cooking step (De Girolamo et al., 2001). During extrusion cooking, the product is forced through metal tubes by rotating screws and is subjected to high T, high pressure, and severe shear. Extrusion usually causes decreases in mycotoxin concentrations. However, the effects on mycotoxin levels is probably influenced by the screw speed and T. Stability of FB1 in corn grits was affected by the extrusion parameters: up to $50 \%$ reduction in $\mathrm{FB} 1$ was measured when the grits were extruded at $160^{\circ} \mathrm{C}$ (Jackson et al., 2012). The effects of extrusion on AF levels was also influenced by the presence or absence of additives, moisture content and T. Extrusion alone reduced AF content by $50-80 \%$, and with addition of ammonia, either as hydroxide (0.7$1.0 \%)$ or as bicarbonate (0.4\%), the decreases in AF levels were greater than 95\% (Jalili, 2015). Inclusion of sugar also altered the stability of FBs during extrusion processing (Castelo et al., 2006). This was also the case for DON for which extrusion decomposed DON, which was more susceptible to extrusion than AFB1 (Cazzaniga et al., 2001).

Traditional nixtamalization production of tortillas, the process of cooking in alkaline solution, is reduced initial total AFs by $60-65 \%$ and FBs by $80 \%$ (Schaarschmidt et al., 2019). This was through physical removal during steeping and washing, and by degradation after application of elevated $\mathrm{pH}$ and high $\mathrm{T}$. However, the reductions varied depending on cooking time $\mathrm{T}$, steeping time, and initial toxin concentration in maize grain (Mendez-Albores et al., 2014). The impacts of different nixtamalization processes on $\mathrm{AF}$ and $\mathrm{FB}$ concentrations was reviewed by Schaarschmidt et al. (2019). Besides reduction in the free parent forms, nixtamalization can also cause modification, and/or binding or release of matrix-associated mycotoxins, but their toxicity has yet to be evaluated (De Girolamo et al., 2016).

\section{Detoxification}

Preventive actions are not effective for fully avoiding mycotoxin contamination, so detoxification methods may still be necessary to recover contaminated commodities. These include the use of physical processes, or chemical and biological additives. The efficacy of these processes in reducing AFB1 was reviewed by Rushing et al., (2019). They reported a reduction range of AFB1 between 51 and $100 \%$ after thermal treatment at Ts between 150 and $200^{\circ} \mathrm{C}$, and exposure times between 20 and $200 \mathrm{~min}$. However, none of the reviewed studies were conducted on maize matrices, but were on other cereals (rice and wheat). Gbashi et al. (2019) examined decontamination effects of heating on maize flour, and demonstrated that AFs (AFB1, AFB2, AFG1) were completely degraded at $217^{\circ} \mathrm{C}$ for $35 \mathrm{~min}$. Heat treatment is a low cost and simple approach for mitigating the presence of mycotoxins. However, thermal stability of mycotox- 
ins requires the use of high Ts and long exposure times, which result in a significant impacts on grain quality factors.

Effects of UV or gamma irradiation have been reported in maize for AFB1 (Markov et al., 2015) and FBs (Mansur et al., 2014). Reductions of AFB1 by radiation were reported to range between 60 and 90\% (Markov et al., 2015).

Chemical treatments have included acidification, ammonization and ozonation, the latter has shown a decontamination rate of AFB1 in maize of $88 \%$ (Luo et al., 2014).

Microbial degradation of mycotoxins in less-toxic products has been examined. These biological treatments include inoculation with Bacillus (Oluwafemi et al., 2010; Noah Badr et al., 2017) or yeast species (Verheecke et al., 2016), and botanical extracts or enzymes from different biological sources (Karlovsky et al., 2016), with reported reductions in mycotoxins of $60-100 \%$. However, all the described methods are remain experimental, and have yet to be considered as practical management strategies for mycotoxin detoxification.

\section{MODELLING, AND EFFECTS OF CLIMATE CHANGE}

Mechanistic models, using weather data as inputs, can predict mycotoxin contamination during the maize growing season and at harvest. They provide valuable support to crop management in a whole food chain view aimed at minimizing mycotoxin contamination. Mechanistic models are available for the prediction of $\mathrm{AF}$ and $\mathrm{FB}$ occurrence in maize crops, based on actual weather data (Battilani et al., 2003; Maiorano et al., 2009; Battilani et al., 2013), but have not been developed for DON contamination. The impacts of cropping systems are yet to be included in these models. The models could be adapted for the post-harvest periods, but this has yet to be considered. Instead, risk maps have been drawn using historical meteorological data inputs to characterize the most common contamination in relevant geographic areas (Battilani and Camardo Leggieri, 2015).

Apart from seasonal prediction and risk maps, the interest in predictive models for mycotoxins contamination in crops is increasing to take account of climate change. At a global level, climate change is expected to have significant impacts on plant biogeography and fungal populations, with consequences on mycotoxin patterns, as confirmed with predictive approaches (Battilani et al., 2016; van der Fels-Klerx et al., 2016), and by field surveys in Europe (Piva et al., 2006; Dobolyi et al., 2013; Levic et al., 2013). Uncertainties in climate conditions and extreme events have been stressed, and also described as crucial at farm levels (Camardo Leggieri et al., 2019), increasing the emerging risk of cooccurring mycotoxins. Predictive models have therefore become important, to address uncertainties and highlight risk conditions on a geographic basis. Predictive models are likely to be important tools in chain management for mycotoxin reduction as support for farmers, extension services and stakeholders. These willrationalize pre- and post-harvest crop and product management, and provide tools to policy makers for relevant strategic decisions.

\section{CONCLUSIONS}

This review has addressed Aspergillus and Fusarium species in maize, and provided an account of available strategies to mitigate the occurrence of AFs, FBs and DON in maize. Mycotoxin contamination with more than one congener, including modified mycotoxin forms, is an issue that needs further investigation, particularly regarding the consequences for human and animal health. A large body of literature exists on fungal growth and mycotoxin production, and on factors impacting plant-pathogen interactions. Research efforts to support the development of mycotoxin prevention strategies have resulted in sound mitigation methods, mainly at preharvest stages (Figure 3). Nevertheless, removal of mycotoxin contamination in maize cannot yet be foreseen, and further efforts are needed to increase the production of maize with mycotoxins below safe levels set by scientific advisory bodies. Key research areas that need further attention include:

- Management of maize genetic resistance, with particular focus on effectiveness towards all mycotoxin producing fungi;

- Increased understanding of plant-pathogen interactions and plant defense mechanisms, including the role of mycotoxins in maize-fungi cross-talk;

- Extension of biocontrol to Fusaria and pest control as sustainable approaches for mycotoxin mitigation;

- Improvement of the performance of predictive models, including investigating the impacts of cropping systems and of co-occurring fungi on model predictions;

- Prediction of future scenarios of mycotoxin occurrence as supporting tools for decision makers;

- Further development of alternative biological tools to be applied post-harvest, to improve safe storage or detoxification of contaminated grain and complete sustainable management of the maize value chain. 


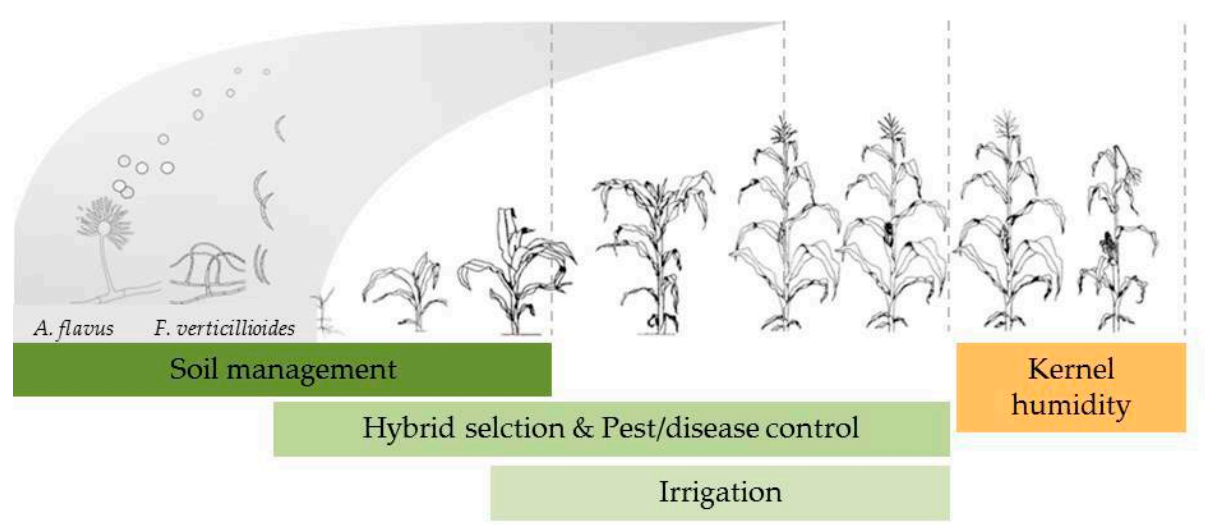

Pre-harvest
Harvest

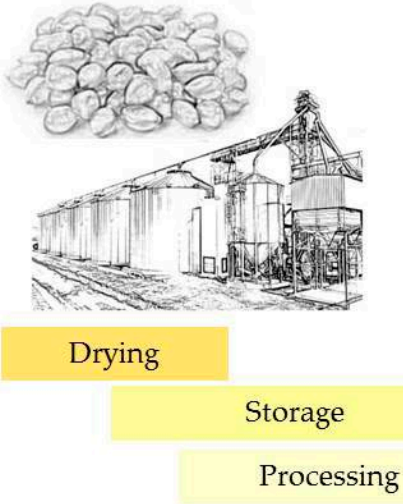

Post-harvest

Figure 3. Crucial action in pre- and post-harvest management of maize to minimize mycotoxin contamination by Aspergillus flavus and Fusarium vertcillioides. Crop phenology is based on the $\mathrm{BBCH}$ scale edited by the Federal Biological Research Centre for Agriculture and Forestry.

Harmonized methodologies for human and animal health risk assessment have been recently developed (EFSA, 2019). Such methodologies need to be applied to multiple mycotoxins, using available co-occurrence data and comparative toxicity metrics, to investigate the potential impacts on human and animal health of multiple mycotoxins, in a range of crops including maize.

\section{ACKNOWLEDGMENTS}

This review was prepared as part of MYCHIF EFSA project (GP/EFSA/AFSCO/2016/01). Roberta Palumbo carried out this work within the PhD school Agrisystem of Università Cattolica del Sacro Cuore, Italy. This study was supported by the Portuguese Foundation for Science and Technology (FCT) under the scope of the strategic funding of UID/BIO/04469 unit and COMPETE 2020 (POCI-01-0145-FEDER-006684) and BioTecNorte operation (NORTE-01-0145-FEDER-000004) funded by the European Regional Development Fund under the scope of Norte2020 - Programa Operacional Regional do Norte. This paper was critically reviewed in collaboration with MycoKey project (Horizon 2020, Grant Agreement No. 678781).

\section{AUTHOR CONTRIBUTIONS}

R. Palumbo: literature review, paper writing. A. Gonçalves: literature review. A. Gkrillas: literature review. A.
Logrieco: paper revision. J. L. Dorne: paper revision. C. Dall'Asta: paper writing and revision. A. Venâncio: conception and design, paper revision. P. Battilani: paper conception and design, paper coordination, revision, and final approval. All authors provided critical feedback and helped to shape the manuscript.

\section{LITERATURE CITED}

Abbas H.K., Mascagni H.J., Jr. Bruns H.A., Shier W.T., 2012. Effect of planting density, irrigation regimes, and maize hybrids with varying ear size on yield, and aflatoxin and fumonisin contamination levels. American Journal of Plant Sciences 3: 1341-1354. DOI:10.4236/ajps.2012.310162

Abbès S., Salah-Abbès J.B., Jebali R., Younes R.B., Oueslati R., 2016. Interaction of aflatoxin B1 and fumonisin B1 in mice causes immunotoxicity and oxidative stress: Possible protective role using lactic acid bacteria. Journal of Immunotoxicology 13: 46-54. DOI:10.3 109/1547691X.2014.997905

Abdallah M.F., De Boevre M., Landschoot S., De Saeger S., Haesaert G., Audenaert K., 2018. Fungal Endophytes Control Fusarium graminearum and Reduce Trichothecenes and Zearalenone in Maize. Toxins 10: 493. DOI:10.3390/toxins 10120493

Abhishek R.U., Thippeswamy S., Manjunath K., Mohana D.C., 2015. Antifungal and antimycotoxigenic potency of Solanum torvum Swartz. leaf extract: isolation and identification of compound active against myco- 
toxigenic strains of Aspergillus flavus and Fusarium verticillioides. Journal of Applied Microbiology 119: 1624-1636. DOI:10.1111/jam.12956

Achugbu A.N., Amadi J.E., Ilodibia C.V., Ikegbunam M.N., 2016. Effects of Garcinia kola and Azadirachta indica seeds in the inhibition of Aspergillus flavus and Aspergillus parasiticus isolated from Zea mays L. Awka, Nigeria. American Journal of Plant Sciences 7: 1555-1563. DOI:10.4236/ajps.2016.711147

Ahlberg S., Joutsjoki V., Korhonen H., Laurikkala S., Varmanen P., 2017. Aspergillus flavus growth inhibition by Lactobacillus strains isolated from traditional fermented Kenyan milk and maize products. Archives of microbiology 199: 457-464. DOI:10.1007/s00203016-1316-3

Alberts J.F., van Zyl W.H., Gelderblom W.C.A., 2016. Biologically based methods for control of fumonisin-producing Fusarium species and reduction of the fumonisins. Frontiers in Microbiology 7: 548. DOI:10.3389/fmicb.2016.00548

Arino A., Herrera M., Juan T., Estopanan G., Carraminana J.J., Rota C., Herrera A., 2009. Influence of agricultural practices on the contamination of maize by fumonisin mycotoxins. Journal of Food Protection 72: 898-902.

Armando M.R., Dogi C.A., Rosa C.A.R., Dalcero A.M., Cavaglieri L.R., 2012. Saccharomyces cerevisiae strains and the reduction of Aspergillus parasiticus growth and aflatoxin B1 production at different interacting environmental conditions, in vitro. Food Additives and Contaminants 29: 1443-1449. DOI:10.1080/1944 0049.2012.698655

Azaiez I., Meca G., Manyes L., Fernandez-Franzon M., 2013. Antifungal activity of gaseous allyl, benzyl and phenyl isothiocyanate in vitro and their use for fumonisins reduction in bread. Food Control 32: 428434. DOI:10.1016/j.foodcont.2013.01.020

Baliukoniene V., Bakutis B., Januskeviciene G., Miseikiene R., 2011. Fungal contamination and Fusarium mycotoxins in cereals grown in different tillage systems. Journal of Animal and Feed Sciences 20: 637-647. DOI:10.22358/jafs/66222/2011

Bandyopadhyay R., Ortega-Beltran A., Akande A., Mutegi C., Atehnkeng J., Kaptoge L., Cotty P.J., 2016. Biological control of aflatoxins in Africa: current status and potential challenges in the face of climate change. World Mycotoxin Journal 9: 771-789. DOI:10.3920/WMJ2016.2130

Bartók T., Szécsi Á., Juhász K., Bartók M., Mesterházy Á., 2013. ESI-MS and MS/MS identification of the first ceramide analogues of fumonisin B1 mycotoxin from a Fusarium verticillioides culture following RP-HPLC separation. Food Additives and Contaminants- Part A Chemistry, Analysis, Control, Exposure and Risk Assessment 30: 1651-1659. DOI:10.1080/19440049.20 13.809626

Battilani P., Rossi V., Pietri A., 2003. Modelling Fusarium verticillioides infection and fumonisin synthesis in maize ears. Aspects of applied biology 1: 91-100.

Battilani P., Barbano C., Piva G., 2008. Aflatoxin B1 contamination in maize related to the aridity index in North Italy. World Mycotoxin Journal 1: 449-456.

Battilani P., Camardo Leggieri M., 2015. Predictive modelling of aflatoxin contamination to support maize chain management. World Mycotoxin Journal 8: 161170. DOI:10.3920/WMJ2014.1740

Battilani P., Rossi V., Giorni P., Pietri A., Gualla A., van der Fels-Klerx H.J., Brera C., 2012. Modelling, predicting and mapping the emergence of aflatoxins in cereals in the EU due to climate change. EFSA Supporting Publication 2012 9: 172. DOI:10.2903/ sp.efsa.2012.EN-223

Battilani P., Camardo Leggieri M., Rossi V., Giorni P., 2013. AFLA-maize, a mechanistic model for Aspergillus flavus infection and aflatoxin B1 contamination in maize. Computers and Electronics in Agriculture 94: 38-46. DOI:10.1016/j.compag.2013.03.005

Battilani P., Toscano P., Van der Fels-Klerx H.J., Moretti A., Camardo Leggieri M., Brera C., ... Robinson T., 2016. Aflatoxin B1 contamination in maize in Europe increases due to climate change. Scientific Reports 6: 24328. DOI:10.1038/srep24328

Battilani P., Lanubile A., Scala V., Reverberi M., Gregori R., Falavigna C., ... Kolomiets M.V., 2018. Oxylipins from both pathogen and host antagonize ja-mediated defense via the 9-lipoxygenase pathway in Fusarium verticillioides infection of maize. Molecular Plant Pathology 19: 2162-2176. DOI:10.1111/mpp.12690

Berthiller F., Schuhmacher R., Adam G., Krska R., 2009a. Formation, determination and significance of masked and other conjugated mycotoxins. Analytical and Bioanalytical Chemistry 395: 1243-1252. DOI:10.1007/ s00216-009-2874-x

Berthiller F., Dall'asta C., Corradini R., Marchelli R., Sulyok M., Krska R., ... Schuhmacher R., $2009 \mathrm{~b}$. Occurrence of deoxynivalenol and its $3-\beta$-D-glucoside in wheat and maize. Food Additives and Contaminants 26: 507-511. DOI: 10.1080/02652030802555668

Bhatnagar D., Payne G., Klich M., Leslie J.F., 2014. Identification of toxigenic Aspergillus and Fusarium species in the maize grain chain. In: Mycotoxin Reduction in Grain Chains (J. F. Leslie, A. F. Logrieco, eds), Wiley Blackwell: Iowa USA, 11-25. 
Blacutt A.A., Mitchell T.R., Bacon C.W., Gold S.E., 2016. Bacillus mojavensis RRC101 lipopeptides provoke physiological and metabolic changes during antagonism against Fusarium verticillioides. Molecular Plant Microbe Interactions 29: 713-723. DOI:10.1094/ mpmi-05-16-0093-r

Blandino M., Reyneri A., Colombari G., Pietri A., 2009a. Comparison of integrated field programmes for the reduction of fumonisin contamination in maize kernels. Field Crops Research 111: 284-289. DOI:10.1016/j.fcr.2009.01.004

Blandino M., Reyneri A., Vanara F., Tamietti G., Pietri A., 2009b. Influence of agricultural practices on Fusarium infection, fumonisin and deoxynivalenol contamination of maize kernels. World Mycotoxin Journal 2: 409-418. DOI:10.3920/WMJ2008.1098

Blandino M., Peila A., Reyneri A., 2009c. Timing clorpirifos + cypermethrin and indoxacarb applications to control European corn borer damage and fumonisin contamination in maize kernels. Journal of the Science of Food and Agriculture 90: 521-529. DOI:10.1002/jsfa.3850

Blandino M., Scarpino V., Vanara F., Sulyok M., Krska R., Reyneri A., 2015. Role of the European corn borer (Ostrinia nubilalis) on contamination of maize with 13 Fusarium mycotoxins. Food Additives \& Contaminants 32: 533-543. DOI:10.1080/19440049.2014.966158

Brown R. L., Menkir A., Chen Z.Y., Bhatnagar D., Yu J., Yao H., Cleveland T.E., 2013. Breeding aflatoxinresistant maize lines using recent advances in technologies - a review. Food Additives \& Contaminants 30: 1382-1391. DOI:10.1080/19440049.2013.812808

Bryła M., Roszko M., Szymczyk K., Jędrzejczak R., Obiedziński M., Sękul J., 2013a. Fumonisins in plantorigin food and fodder-a review. Food Additives and Contaminants- Part A Chemistry, Analysis, Control, Exposure and Risk Assessment 30: 1626-1640. DOI:1 0.1080/19440049.2013.809624

Bryła M., Jezdrzejczak R., Roszko M., Szymczyk K., Obiedzinski M. W., Sekul J., Rzepkowska M., 2013b. Application of molecularly imprinted polymers to determine B1,B 2, and B3 fumonisins in cereal products. Journal of Separation Science 36: 578-584. DOI:10.1002/jssc.201200753

Bryła M., Roszko M., Szymczyk K., Jędrzejczak R., Słowik E., Obiedzinski M.W., 2014. Effect of baking on reduction of free and hidden fumonisins in glutenfree bread. Journal of Agricultural and Food Chemistry 62: 10341-10347. DOI:10.1021/jf504077m

Bryła M., Szymczyk K., Jedrzejczak R., Obiedzinski M. W., 2015. Free and hidden fumonisins in various fractions of maize dry milled under model condi- tions. LWT-Food Science and Technology 64: 171-176. DOI:org/10.1016/j.lwt.2015.05.048

Bullerman L.B., Bianchini A., 2014. Good food-processing techniques: Stability of mycotoxins in processed maize-based foods. In: Mycotoxin Reduction in Grain Chains (J. F. Leslie, A. F. Logrieco, eds), Wiley Blackwell: Ames, Iowa 50010, USA, 978-971.

Caceres I., El Khoury R., Medina Á., Lippi Y., Naylies C., Atoui A., ... Puel O., 2016. Deciphering the anti-aflatoxinogenic properties of eugenol using a large-scale q-PCR approach. Toxins 8: 123. DOI:10.3390/toxins8050123

Camardo Leggieri M., Lanubile A., Dall'Asta A., Pietri A., Battilani P., 2019. The impact of seasonal weather variation on mycotoxins: maize crop in 2014 in northern Italy as a case study. World Mycotoxin Journal in press. DOI:10.3920/WMJ2019.2475

Camardo Leggieri M., Bertuzzi T., Pietri A., Battilani P., 2015. Mycotoxin occurrence in Italian maize produced in 2009-2011 and focus on the role of crop related factors. Phytopathologia Mediterranea 53: 459-469. DOI:10.14601/Phytopathol_Mediterr-14632

Cano-Sancho G., Ramos A.J., Marín S., Sanchis V., 2012. Presence and co-occurrence of aflatoxins, deoxynivalenol, fumonisins and zearalenone in glutenfree and ethnic foods. Food Control 26: 282-286. DOI:10.1016/j.foodcont.2012.01.052

Cary J.W., Ehrlich K.C., 2006. Aflatoxigenicity in Aspergillus: molecular genetics, phylogenetic relationships and evolutionary implications. Mycopathologia 162: 167-177. DOI:10.1007/s11046-006-0051-8

Cary J.W., Rajasekaran K., Brown R.L., Luo M., Chen Z. Y., Bhatnagar D., 2011. Developing resistance to aflatoxin in maize and cottonseed. Toxins 3: 678-696. DOI:10.3390/toxins3060678

Castelo M., Katta K., Sumner S., Milford A., Bullerman L., 2006. Extrusion cooking reduces recoverability of Fumonisin B1 from extruded corn grits. Journal of Food Science 63: 696-698. DOI:10.1111/j.1365-2621.1998.tb15815.x

Cazzaniga D., Basílico J.C., González R.J., Torres R.L., de Greef D.M., 2001. Mycotoxins inactivation by extrusion cooking of corn flour. Letters in Applied Microbiology 33. DOI:10.1046/j.1472-765x.2001.00968.x

Chen Z.Y., Brown R.L., Cleveland T.E., Damann K.E., Russin J. S., 2001. Comparison of constitutive and inducible maize kernel proteins of genotypes resistant or susceptible to aflatoxin production. Journal of Food Protection 64: 1785-1792. DOI:10.4315/0362028X-64.11.1785

Chen Z.Y., Rajasekaran K., Brown R.L., Sayler R.J., Bhatnagar D., 2015. Discovery and confirmation of genes/ 
proteins associated with maize aflatoxin resistance. World Mycotoxin Journal 8: 211-224. DOI:10.3920/ wmj2014.1732

Coma V., Portes E., Gardrat C., Richard-Forget F., Castellan A., 2011. In vitro inhibitory effect of tetrahydrocurcuminoids on Fusarium proliferatum growth and fumonisin B1 biosynthesis. Food Additives \& Contaminants 28: 218-225. DOI:10.1080/19440049.2010. 540721

Coradi P.C., Maier D.E., Channaiah L.H., Campabadal C., 2016. Effects of the processing on the distribution of aflatoxin and fumonisin levels in corn fractions and feeds. Journal of Food Process Engineering 39: 215225. DOI:10.1111/jfpe.12212

Cotten T.K., Munkvold G.P., 1998. Survival of Fusarium moniliforme, F. proliferatum, and F. subglutinans in maize stalk residue. Phytopathology 88: 550-555.

Cotty P.J., Bayman P., 1993. Competitive exclusion of atoxigenic strain of Aspergillus flavus by an atoxigenic strain. Phytopathology 83: 1283-1287. DOI: 10.1094/ Phyto-83-1283

Cotty P.J., 2006. Biocompetitive exclusión of toxigenic fungi. In: The mycotoxin factbook: food and feed topics (D. Barug, D. Bhatnagar, H. P. van Egmond, J. W. van der Kamp, W. A. van Osenbruggen, \& A. Visconti, eds), Wageningen Academic Marijkeweg 22, 6709 PG Wageningen, The Netherlands, 179-192.

Da Gloria E.M., Mengai B., Steffen Almeida G., Cuccovia Mazotti N.C., Tadeu dos Santos Dias C., Moreira e Moreira R., ... Calori Domingues M.A. (2010). Effect of essential oils from Eucalyptus on the growth of aflatoxigenic species. Paper presented at the 10th International Working Conference on Stored Product Protection, Brazil.

Dall'Asta C., Mangia M., Berthiller F., Molinelli A., Sulyok M., Schuhmacher R., ... Marchelli R., 2009. Difficulties in fumonisin determination: The issue of hidden fumonisins. Analytical and Bioanalytical Chemistry 395: 1335-1345. DOI:10.1007/s00216009-2933-3

Dall'Asta C., Falavigna C., Galaverna G., Dossena A., Marchelli R., 2010. In vitro digestion assay for determination of hidden fumonisins in maize. Journal of Agricultural and Food Chemistry 58: 12042-12047. DOI:10.1021/jf103799q

Dall'Asta C., Falavigna C., Galaverna G., Battilani P., 2012. Role of maize hybrids and their chemical composition in Fusarium infection and fumonisin production. Journal of Agricultural and Food Chemistry 60: 0021-8561. DOI:10.1021/jf300250z

Dall'Asta C., Giorni P., Cirlini M., Reverberi M., Gregori R., Ludovici M., Scala V., 2015. Maize lipids play a pivotal role in the fumonisin accumulation. World Mycotoxin Journal 8: 87-97. DOI:10.3920/ wmj2014.1754

Dall'Asta C., Battilani P., 2016. Fumonisins and their modified forms, a matter of concern in future scenario? World Mycotoxin Journal 9: 727-739. DOI:10.3920/WMJ2016.2058

Damianidis D., Ortizb B.V., Windhamc G.L., Bowend K.L., Hoogenboome G., Scullyf B.T., ... Williamsc W. P., 2018. Evaluating a generic drought index as a predictive tool for aflatoxin contamination of corn: From plot to regional level. Crop Protection 113: 64-74. DOI:10.1016/j.cropro.2018.07.013

De Boevre M., Di Mavungu D.J., Landschoot S., Audenaert K., Eeckhout M., Maene P., ... De Saeger S., 2012. Natural occurrence of mycotoxins and their masked forms in food and feed products. World Mycotoxin Journal 5: 207-219. DOI:10.3920/ WMJ2012.1410

De Girolamo A., Solfrizzo M., Visconti A., 2001. Effect of processing on fumonisin concentration in corn flakes. Food Protection Trends 64: 701-705.

De Girolamo A., Lattanzio V.M.T., Schena R., Visconti A., Pascale M., 2016. Effect of alkaline cooking of maize on the content of fumonisins $\mathrm{B} 1$ and $\mathrm{B} 2$ and their hydrolysed forms. Food Chemistry 192: 1083-1089. DOI:10.1016/j.foodchem.2015.07.059

De Lucca A.J., Carter-Wientjes C.H., Boue S.M., Lovisa M.P., Bhatnagar D., 2013. Inhibition of bacterial and filamentous fungal growth in high moisture, nonsterile corn with intermittent pumping of trans-2-hexenal vapor. Journal of Food Science 78: 1029-1035. DOI:10.1111/1750-3841.12151

Deepthi B.V., Rao K. P., Chennapa G., Sreenivasa M.Y., Naik M.K., Chandrashekara K.T., 2016. Antifungal attributes of Lactobacillus plantarum MYS6 against fumonisin producing Fusarium proliferatum associated with poultry feeds. PLoS One 11: 1932-6203. DOI:10.1371/journal.pone.0155122

Desmarchelier A., Seefelder W., 2011. Survey of deoxynivalenol and deoxynivalenol-3-glucoside in cereal-based products by liquid chromatography electrospray ionization tandem mass spectrometry. World Mycotoxin Journal 4: 29-35. DOI:10.3920/ WMJ2010.1236

Dobolyi C., Sebok F., Varga J., Kocsube S., Szigeti G., Baranyi N., ... Kukolya J., 2013. Occurrence of aflatoxin producing Aspergillus flavus isolates in maize kernel in Hungary. Acta Alimentaria 42: 451-459. DOI:10.1556/AAlim.42.2013.3.18

Domijan A.M., Peraica M., Cvjetkovij B., Turcin S., Jurjevic Z., Ivic D., 2005. Mould contamination and co- 
occurrence of mycotoxins in maize grain in Croatia. Acta Pharmaceutica 55: 349-356.

Drakulic J., Ray R.V., Bruce T.J.A., 2017. Direct and hostmediated interactions between Fusarium pathogens and herbivorous arthropods in cereals. Plant Pathology 66: 3-13. DOI:I 10.1111/ppa.12546

Eckard S., Wettstein F.E., Forrer H.R., Vogelgsang S., 2011. Incidence of Fusarium species and mycotoxins in silage maize. Toxins 3: 949-967. DOI:10.3390/toxins3080949

EFSA. 2004. Opinion of the Scientific Panel on Contaminants in the Food Chain on a request from the Commission related to Aflatoxin B1 as undesirable substance in animal feed. EFSA Journal 39: 1-27.

EFSA., More S. J., Bampidis V., Benford D., Bennekou S. H., Bragard C., ... Hogstrand C., 2019. Guidance on harmonised methodologies for human health, animal health and ecological risk assessment of combined exposure to multiple chemicals. EFSA Journal EFSA Journal 17: 5634-5677. DOI: 10.2903/j.efsa.2019.5634

Elsamra I.A., Shama S.M., Hamza A.S., Youssef N.H., Youssef M.S., Alabd S.M., 2012. Effect of some mould inhibitors and herbal plants on mycotoxins production by Aspergillus flavus and Fusarium verticilloides in vitro and in stored corn grains. Archives of Phytopathology and Plant Protection 45: 1861-1878. DOI:1 0.1080/03235408.2012.713799

Eskola M., Altieri A., Galobart J., 2018. Overview of the activities of the European Food Safety Authority on mycotoxins in food and feed. World Mycotoxin Journal 11: 277-289. DOI:10.3920/WMJ2017.2270

European Commission, 2006a. Regulation (576/2006) on the presence of deoxynivalenol, zearalenone, ochratoxin A, T-2 and HT-2 and fumonisins in products intended for animal feeding. Official Journal of the European Union 229: 7-9.

European Commission, 2006b. Regulation (1881/2006) setting maximum levels for certain contaminants in foodstuffs. Official Journal of the European Union 364: 4-24.

European Commission, 2011. Regulation (574/2011) amending Annex I to Directive 2002/32/EC of the European Parliament and of the Council as regards maximum levels for nitrite, melamine, Ambrosia spp. and carry-over of certain coccidiostats and histomonostats and consolidating Annexes I and II thereto. Official Journal of the European Union 159: 7-23.

European Commission, 2013. Recommendations (165/2013) on the presence of T-2 and HT-2 toxin in cereals and cereal products. Official Journal of the European Union 91: 12-15.

European Commission, 2019. Short-term outlook for EU agricultural markets in 2018 and 2019. Retrieved from https://ec.europa.eu/agriculture/markets-andprices/short-term-outlook_en

Eurostat, 2019. Agriculture, forestry and fishery statistical book. Retrieved from https://ec.europa.eu/eurostat/ statistics-explained/index.php?title=Agricultural_production_-_crops

Falavigna C., Cirlini M., Galaverna G., Dall'Asta C., 2012. Masked fumonisin in processed food: co-occurrence of hiddend and bound forms and stability under digestive conditions. World Mycotoxin Journal 5: 325-334. DOI:10.3920/WMJ2012.1403

Falavigna C., Lazzaro I., Galaverna G., Dall'Asta C., Battilani P., 2016. Oleoyl and linoleoyl esters of fumonisin B1 are differently produced by Fusarium verticillioides on maize and rice based media. International Journal of Food Microbiology 217. DOI:10.1016/j. ijfoodmicro.2015.10.013

Fandohan P., Zoumenou D., Hounhouigan D.J., Marasas W.F.O., Wingfield M.J., Hell K., 2005. Fate of aflatoxins and fumonisins during the processing of maize into food products in Benin. International Journal of Food Microbiology 98: 249-259. DOI:10.1016/j.ijfoodmicro.2004.07.007

Farfan I.D.B., De La Fuente G.N., Murray S.C., Isakeit T., Huang P.C., Warburton M., Kolomiets M., 2015. Genome wide association study for drought, aflatoxin resistance, and important agronomic traits of maize hybrids in the sub-tropics. PLoS ONE 10: 1932-6203. DOI:10.1371/journal.pone.0117737

Ferrochio L., Cendoya E., Farnochi M.C., Massad W., Ramirez M.L., 2013. Evaluation of ability of ferulic acid to control growth and fumonisin production of Fusarium verticillioides and Fusarium proliferatum on maize based media. International Journal of Food Microbiology 167: 215-220. DOI:10.1016/j.ijfoodmicro.2013.09.005

Figueroa-López A.M., Cordero-Ramírez J.D., MartínezÁlvarez J.C., López-Meyer M., Lizárraga-Sánchez G.J., Félix-Gastélum R., Maldonado-Mendoza I.E., 2016. Rhizospheric bacteria of maize with potential for biocontrol of Fusarium verticillioides. SpringerPlus 5: 330. DOI:10.1186/s40064-016-1780-x

Folcher L., Marc J., Weissenberger A., Gérault F., Eychenne N., Délos M., Regnault-Roger C., 2009. Comparative activity of agrochemical treatments on mycotoxin levels with regard to corn borers and Fusarium mycoflora in maize (Zea mays L.) fields. Crop Protection 28: 302-308. DOI:10.1016/j.cropro.2008.11.007

Folcher L., Weissenberger A., Delos M., 2012. Quantitative relationships between Ostrinia nubilalis activity and deoxynivalenol contamination in French maize. 
International Journal of Pest Management 58: 302309. DOI:10.1080/09670874.2012.679641

Fumero M.V., Sulyok M., Chulze S., 2016. Ecophysiology of Fusarium temperatum isolated from maize in Argentina. Food Additives and Contaminants - Part A Chemistry, Analysis, Control, Exposure and Risk Assessment 33: 147-156. DOI:10.1080/19440049.2015.1107917

Garcia-Cela E., Kiaitsi E., Sulyok M., Krska R., Medina A., Petit Damico I., Magan N., 2019. Influence of storage environment on maize grain: $\mathrm{CO} 2$ production, dry matter losses and aflatoxins contamination. Food Additives and Contaminants. DOI:10.1080/1944 0049.2018.1556403

Garcia D., Ramos A., Sanchis V., Marin S., 2012. Effect of Equisetum arvense and Stevia rebaudiana extracts on growth and mycotoxin production by Aspergillus flavus and Fusarium verticillioides in maize seeds as affected by water activity. International Journal of Food Microbiology 153: 1-2. DOI:10.1016/j.ijfoodmicro.2011.10.010

Gbashi S., Madala N. E., De Saeger S., De Boevre M., Njobeh P. B., 2019. Numerical optimization of temperature-time degradation of multiple mycotoxins. Food and Chemical Toxicology 125: 289-304. DOI:10.1016/j.fct.2019.01.009

Generotti S., Cirlini M., Dall'Asta C., Suman M., 2015. Influence of the industrial process from caryopsis to cornmeal semolina on levels of fumonisins and their masked forms. Food Control 48: 170-174. DOI:10.1016/j.foodcont.2014.06.003

Giorni P., Magan N., Pietri A., Bertuzzi T., Battilani P., 2007. Studies on Aspergillus section Flavi isolated from maize in northern Italy. International Journal of Food Microbiology 113: 330-338. DOI:10.1016/j. ijfoodmicro.2006.09.007

Giorni P., Magan N., Pietri A., Battilani P., 2011. Growth and aflatoxin production of an Italian strain of Aspergillus flavus: influence of ecological factors and nutritional substrates. World Mycotoxin Journal 4: 425432. DOI:10.3920/wmj2011.1300

Giorni P., Formenti S., Bertuzzi T., Magan N., Battilani P., 2014. Influence of water activity and anti-fungal compounds on development and competitiveness of Fusarium verticillioides. Phytopathologia Mediterranea 53: 459-469.

Giorni P., Dall'Asta C., Gregori R., Cirlini M., Galaverna G., Battilani P., 2015. Starch and thermal treatment, important factors in changing detectable fumonisins in maize post-harvest. Journal of Cereal Science 61: 78-85. DOI:10.1016/j.jcs.2014.10.006

Giorni P., Bertuzzi T., Battilani P., 2016. Aflatoxin in maize, a multifaceted answer of Aspergillus fla- vus governed by weather, host-plant and competitor fungi. Journal of Cereal Science 70: 256-262. DOI:10.1016/j.jcs.2016.07.004

Görtz A., Oerke E. C., Steiner U., Dehne H. W. (2008, 6-10 May 2007). Incidence and Control of Fusarium Ear Rot of Maize. Paper presented at the Modern fungicides and antifungal compounds V: 15th International Reinhardsbrunn Symposium, Friedrichroda Germany.

Gregori R., Meriggi P., Pietri A., Formenti S., Baccarini G., Battilani P., 2013. Dynamics of fungi and related mycotoxins during cereal storage in silo bags. Food Control 30: 280-287. DOI:10.1016/j.foodcont.2012.06.033

Horn B. W., 2003. Ecology and population biology of aflatoxigenic fungi in soil. Journal of Toxicology 22: 351-379. DOI:10.1081/TXR-120024098

Horn B. W., Moore G. G., Carbone I., 2009. Sexual reproduction in Aspergillus flavus. Mycologia 101: 423-429. DOI:10.3852/09-011

Horn B. W., Gell R. M., Singh R., Sorensen R. B., Carbone I., 2016. Sexual reproduction in Aspergillus flavus sclerotia: acquisition of novel alleles from soil populations and uniparental mitochondrial inheritance. PLoS One 11: 1. DOI:10.5061/dryad.sk35h

Hu S., Stroshine R. L., Ileleji K., 2017. Differences in kernel shape, size, and density between healthy kernels and mold discolored kernels and their relationship to reduction in aflatoxin levels in a sample of shelled corn. Applied Engineering in Agriculture 33: 421-431.

Hua S. T., Beck J. J., Sarreal S. B. L., Gee W., 2014. The major volatile compound 2-phenylethanol from the biocontrol yeast, Pichia anomala, inhibits growth and expression of aflatoxin biosynthetic genes of Aspergillus flavus. Mycotoxin Research 30: 71-78. DOI:10.1007/s12550-014-0189-z

Humpf H. U., Voss K. A., 2004. Effect of thermal food processing on the chemical structure and toxicity of fumonisin mycotoxins. Molecular Nutrition and Food Research 48: 255-269.

Ingenbleek L., Sulyok M., Adegboye A., Hossou S. E., Koné A. Z., Oyedele A. D., ... Krska R., 2019. Regional Sub-Saharan Africa total diet study in Benin, Cameroon, Mali and Nigeria reveals the presence of 164 mycotoxins and other secondary metabolites in foods. Toxins 11: 54. DOI: 10.3390/toxins 11010054

Jackson L. S., Jackson L. S., Voss K. A., Ryu D., 2012. Effects of different extrusion conditions on the chemical and toxicological fate of fumonisin B-1 in maize: a short review. World Mycotoxin Journal 5: 251-260. DOI:I 10.3920/wmj2012.1431 
Jalili M., 2015. A Review on Aflatoxins Reduction in Food. Iranian Journal of Health, Safety and Environment 3: 445-459.

Jiang T., Zhou B., Luo M., Abbas Hamed K., Kemerait R., Lee Robert D., Guo B., 2011. Expression analysis of stress-related genes in kernels of different maize (Zea mays L.) inbred lines with different resistance to aflatoxin contamination. Toxins 3: 538-550. DOI:10.3390/toxins3060538

Jurjevic Z., Solfrizzo M., Cvjetkovic B., De Girolamo A., Visconti A., 2002. Occurrence of beauvericin in corn from Croatia. Food Technology and Biotechnology 40: 91-94.

Kalagatur N. K., Mudili V., Siddaiah C., Gupta V. K., Natarajan G., Sreepathi M. H., ... Putcha V. L. R., 2015. Antagonistic activity of Ocimum sanctum L. essential oil on growth and zearalenone production by Fusarium graminearum in maize grains. Frontiers in Microbiology 6: 1664-1302. DOI:10.3389/fmicb.2015.00892

Karlovsky P., Suman M., Berthiller F., De Meester J., Eisenbrand G., Perrin I., ... Dussort P., 2016. Impact of food processing and detoxification treatments on mycotoxin contamination. Mycotoxin Research 32: 179-205. DOI:I 10.1007/s12550-016-0257-7

Kelley R. Y., Williams W. P., Mylroie J. E., Boykin D. L., Harper J. W., Windham G. L., Xueyan S., 2012. Identification of maize genes associated with host plant resistance or susceptibility to Aspergillus flavus infection and aflatoxin accumulation. PLoS One 7: 19326203. DOI:10.1371/journal.pone.0036892

Khalil A., Abdellatef A. A., Abou-Gabal A. E., Khaled A. E., Elfaramawy A. M., 2013. Lactic acid bacteria as antimycotic and antimycotoxins agents against toxigenic Fusarium species associated to maize grains stored in Egyptian markets. Journal of Pure and Applied Microbiology 7: 93-105.

Kirincic S., Skrjanc B., Kos N., Kozolc B., Pirnat N., Tavcar-Kalcher G., 2015. Mycotoxins in cereals and cereal products in Slovenia - Official control of foods in the years 2008-2012. Food Control 50: 157-165.

Koc F., Kara S., 2014. Environmental factors affecting efficacy of some essential oils and potassium sorbate to control growth of Aspergillus flavus, Aspergillus parasiticus on wheat and maize grains. Journal of Agricultural Science and Technology 16: 1325-1334.

Kong Q., Chi C., Yu J., Shan S., Li Q., Li Q., ... Bennett J. W., 2014. The inhibitory effect of Bacillus megaterium on aflatoxin and cyclopiazonic acid biosynthetic pathway gene expression in Aspergillus flavus. Applied microbiology and biotechnology 98: 51615172. DOI:10.1007/s00253-014-5632-8

Kosegarten C. E., Ramirez-Corona N., Mani-Lopez E.,
Palou E., Lopez-Malo A., 2017. Description of Aspergillus flavus growth under the influence of different factors (water activity, incubation temperature, protein and fat concentration, $\mathrm{pH}$, and cinnamon essential oil concentration) by kinetic, probability of growth, and time-to-detection models. International Journal of Food Microbiology 240: 115-123. DOI:10.1016/j.ijfoodmicro.2016.04.024

Kovalsky P., Kos G., Nährer K., Schwab C., Jenkins T., Schatzmayr G., ... Krska R., 2016. Co-Occurrence of regulated, masked and emerging mycotoxins and secondary metabolites in finished feed and maize-An extensive survey. Toxins 8: 363.

Lanubile A., Pasini L., Lo Pinto M., Battilani P., Prandini A., Marocco A., 2011. Evaluation of broad spectrum sources of resistance to Fusarium verticillioides and advanced maize breeding lines. World Mycotoxin Journal 4: 43-51. DOI:10.3920/WMJ2010.1206

Lanubile A., Maschietto V., Borrelli V. M., Stagnati L., Logrieco A. F., Marocco A., 2017. Molecular Basis of Resistance to Fusarium Ear Rot in Maize. Frontiers in Plant Science 8: 1774. DOI:10.3389/fpls.2017.01774

Lazzaro I., Susca A., Mule G., Ritieni A., Ferracane R., Marocco A., Battilani P., 2012. Effects of temperature and water activity on FUM2 and FUM21 gene expression and fumonisin B production in Fusarium verticillioides. European Journal of Plant Pathology 134: 685-695. DOI:10.1007/s10658-012-0045-y

Lazzaro I., Moretti A., Giorni P., Brera C., Battilani P., 2015. Organic vs conventional farming: Differences in infection by mycotoxin-producing fungi on maize and wheat in Northern and Central Italy. Crop Protection 72: 22-30. DOI:10.1016/j.cropro.2015.03.001

Leslie J.F., Logrieco A.F., 2014. Mycotoxin Reduction in Grain Chains. Wiley Blackwell, Ames, Iowa, USA, 352 pp.

Levic J., Gosic-Dondo S., Ivanovic D., Stankovic S., Krnjaja V., Bocarov-Stancic A., Stepanic A., 2013. An outbreak of Aspergillus species in response to environmental conditions in Serbia. Pestic Phytomed 28: 167-179. DOI:10.2298/PIF1303167L

Liang D., Xing F., Selvaraj J., Liu X., Wang L., Hua H., ... Liu Y., 2015. Inhibitory effect of cinnamaldehyde, citral, and eugenol on aflatoxin biosynthetic gene expression and aflatoxin B1 biosynthesis in Aspergillus flavus. Journal of Food Science 80: 2917-2923. DOI:10.1111/1750-3841.13144

Llorens A., Mateo R., Hinojo M. J., Valle-Algarra F. M., Jimenez M., 2004. Influence of environmental factors on the biosynthesis of type B trichothecenes by isolates of Fusarium spp. from Spanish crops. International Journal of Food Microbiology 94: 43-54. 
Logrieco A., Mulè G., Moretti A., Bottalico A., 2002. Toxigenic Fusarium species and mycotoxins associated with maize ear rot in Europe. European Journal of Plant Pathology 108: 597-609. DOI:10.1023/A:1020679029993

Logrieco A., Miller J. D., Eskola M., Krska R., Ayalew A., Bandyopadhyay R., ... J.F. L., 2018. The Mycotox Charter: increasing awareness of, and concerted action for, minimizing mycotoxin exposure worldwide. Toxins 10: 1-17. DOI:10.3390/toxins10040149

Ludovici M., Ialongo C., Reverberi M., Beccaccioli M., Scarpari M., Scala V., 2014. Quantitative profiling of oxylipins through comprehensive LC-MS/MS analysis of Fusarium verticillioides and maize kernels. Food Additives \& Contaminants, Part A: Chemistry, Analysis, Control, Exposure \& Risk Assessment 31: 20262033. DOI:10.1080/19440049.2014.968810

Luo M., Liu J., Lee R. D., Guo B. Z., 2008. Characterization of gene expression profiles in developing kernels of maize (Zea mays) inbred Tex6. Plant Breeding 127: 569-578. DOI:10.1111/j.1439-0523.2008.01538.x

Luo M., Brown R. L., Chen Z. Y., Menkir A., Yu J., Bhatnagar D., 2011. Transcriptional profiles uncover Aspergillus flavus-induced resistance in maize kernels. Toxins 3: 766-786. DOI:10.3390/toxins3070766

Luo X., Wang R., Wang L., Li Y., Wang Y., Chen Z., 2014. Detoxification of aflatoxin in corn flour by ozone. Journal of the Science of Food and Agriculture 94: 2253-2258. DOI:10.1002/jsfa.6550

Luongo L., Galli M., Corazza L., Meekes E., Haas L., Plas L. C., 2005. Potential of fungal antagonists for bio-control of Fusarium spp. in wheat and maize through competition in crop debris. Biocontrol Science and Technology 15: 229-242. DOI:10.1080/09583150400016852

Maiorano A., Reyneri A., Sacco D., Magni A., Ramponi C., 2009. A dynamic risk assessment model (FUMAgrain) of fumonisin synthesis by Fusarium verticillioides in maize grain in Italy. Crop Protection 28: 243-256.

Manstretta V., Rossi V., 2015. Effects of weather variables on ascospore discharge from Fusarium graminearum perithecia. PLoS One 10: 1932-6203. DOI:10.1371/ journal.pone.0138860

Manstretta V., Rossi V., 2016. Effects of temperature and moisture on development of Fusarium graminearum perithecia in maize stalk residues. Applied and Environmental Microbiology 82: 184-191. DOI:10.1128/ aem.02436-15

Mansur A. R., Yu C. C., Oh D. H., 2014. Efficiency of gamma irradiation to inactivate growth and fumonisin production of Fusarium moniliforme on corn grains. Journal of Microbiology and Biotechnology 24: 209-216.

Markov K., Mihaljević B., Domijan A. M., Pleadin J., Delaš F., Frece J., 2015. Inactivation of aflatoxigenic fungi and the reduction of aflatoxin B-1 in vitro and in situ using gamma irradiation. Food Control 54: 79-85. DOI:10.1016/j.foodcont.2015.01.036

Martín Castaño S., Medina A., Magan N., 2017. Impact of storage environment on respiration, dry matter losses and fumonisin B1 contamination of stored paddy and brown rice. World Mycotoxin Journal 10: 319-326. DOI:10.3920/WMJ2017.2237

Mason L. J., Woloshuk C. P., 2010. Maximize grain quality and profits using S.L.A.M. Retrieved from http:// extension.entm.perdue.edu/grainlab/content/pdf/ ID-207.pdf

Matasyoh J. C., Wagara I. N., Nakavuma J. L., Kiburai A. M., 2011. Chemical composition of Cymbopogon citratus essential oil and its effect on mycotoxigenic Aspergillus species. African Journal of Food Science 5: 138-142.

Mauro A., Battilani P., Cotty P. J., 2015. Atoxigenic Aspergillus flavus endemic to Italy for biocontrol of aflatoxins in maize. BioControl 60: 125-134. DOI:10.1007/ s10526-014-9624-5

Mauro A., Garcia-Cela E., Pietri A., Cotty P. J., Battilani P., 2018. Biological control products for aflatoxin prevention in Italy: Commercial field evaluation of atoxigenic Aspergillus flavus active ingredients. Toxins 10. DOI:10.3390/toxins10010030

Mazzoni E., Scandolara A., Giorni P., Pietri A., Battilani P., 2011. Field control of Fusarium ear rot, Ostrinia nubilalis (Hubner), and fumonisins in maize kernels. Pest Management Science 67: 458-465. DOI:10.1002/ ps.2084. Epub 2011 Jan 6

Medina-Cordova N., Lopez-Aguilar R., Ascencio F., Castellanos T., Campa-Cordova A. I., Angulo C., 2016. Biocontrol activity of the marine yeast Debaryomyces hansenii against phytopathogenic fungi and its ability to inhibit mycotoxins production in maize grain (Zea mays L.). Biological Control 97: 70-79. DOI:10.1016/j. biocontrol.2016.03.006

Medina A., Magan N., Schmidt-Heydt M., Geisen R., Cardenas-Chavez D. L., Parra R., 2013. Integrating toxin gene expression, growth and fumonisin B-1 and B-2 production by a strain of Fusarium verticillioides under different environmental factors. Journal of The Royal Society Interface 10: 1742-5689. DOI:10.1098/rsif.2013.0320

Mendez-Albores A., Cardenas-Rodriguez Denisse A., Vazquez-Duran A., 2014. Efficacy of microwaveheating during alkaline processing of fumonisin-con- 
taminated maize. Iranian journal of public health 43: 147-155.

Mohanlall R., Odhav B., Mohanlall V., 2013. The effect of thermal processing on fumonisin B1(FB1) levels in maize-based foods. African Journal of Food Science 7: $45-50$.

Monaci L., De Angelis E., Pascale M., Visconti A., 2013. Effect of bread making on the levels of deoxynivalenol, T-2 and HT-2 toxins and their conjugated forms. Tecnica Molitoria 64: 974-982.

Munkvold G. P., Carlton W. M., 1997. Influence of inoculation method on systemic Fusarium moniliforme infection of maize plants grown from infected seeds. Plant Disease 81: 211-216.

Munkvold G. P., McGee D. C., Carlton W. M., 1997. Importance of different pathways for maize kernel infection by Fusarium moniliforme. Phytopathology 2: 209.

Munkvold G. P., 2014. Crop management practices to minimize the risk of mycotoxins contamination in temperate-zone maize. In: Mycotoxin Reduction in Grain Chains (J. F. Leslie, A. F. Logrieco, eds), Wiley Blackwell, Ames, Iowa, USA, 2083-2085.

Murillo-Williams A and Munkvold GP, 2008. Systemic infection by Fusarium verticillioides in maize plants grown under three temperature regimes. Plant Disease 92:1695-1700. DOI:10.1094/PDIS-92-12-1695

Murphy P. A., Rice L. G., Ross P. F., 1993. FumonisinB1, fumonisin B2, and fumonisin B3 content of Iowa,Wisconsin, and Illinois corn and corn screenings. Journal of Agricultural and Food Chemistry 41: 263-266. DOI:10.1021/jf00026a024

Mylona K., Magan N., 2011. Fusarium langsethiae: storage environment influences dry matter losses and T2 and HT-2 toxin contamination of oats. Journal of Stored Products Research 47: 321-327. DOI: 10.1016/j.jspr.2011.05.002

Mylona K., Sulyok M., Magan N., 2012. Relationship between environmental factors, dry matter loss and mycotoxin levels in stored wheat and maize infected with Fusarium species. Food Additives \& Contaminants 29: 1118-1128. DOI: 10.1080/19440049.2012.672340

Nakagawa H., Sakamoto S., Sago Y., Kushiro M., Nagashima H., 2013. Detection of masked mycotoxins derived from type A trichothecenes in corn by highresolution LC-Orbitrap mass spectrometer. Food Additives \& Contaminants: Part A 30: 1407-1414. DOI:10.1080/19440049.2013.790087

Nayaka S. C., Niranjana S. R., Shankar A., Raj S. N., Reddy M. S., Prakash H. S., Mortensen C. N., 2010. Seed biopriming with novel strain of Trichoderma harzianum for the control of toxigenic Fusarium verticillioides and fumonisins in maize. Archives of Phytopathology and Plant Protection 1: 265-284. DOI:10.1080/03235400701803879

Noah Badr A., Amra H. A., Youssef M. M., Logrieco A. F., 2017. Ability of Bacillus Amyloliquefaciens isolated from corn on mycotoxins degradation. Research Journal of Pharmaceutical, Biological and Chemical Sciences 8: 1994-2004.

Numanoglu E., Gökmen V., Uygun U., Koksel H., 2012. Thermal degradation of deoxynivalenol during maize bread baking. Food Additives \& Contaminants 29: 423-430. DOI:10.1080/19440049.2011.644812

Ojiambo P., Battilani P., Cary J., Bluhm B., Carbone I., 2018. Cultural and genetic approaches to manage aflatoxin contamination: recent insights provide opportunities for improved control. Phytopathology 108: 1024-1037. DOI:10.1094/PHYTO-04-18-0134RVW

Oldenburg E., Schittenhelm S., 2012. Effect of plant water deficit on the deoxynivalenol concentration in Fusarium-infected maize kernels. Mycotoxin Research 28: 229. DOI:10.1007/s12550-012-0136-9

Oliveira M. S., Diel A. C. L., Rauber R. H., Fontoura F. P., Mallmann A., Dilkin P., Mallmann C. A., 2015. Free and hidden fumonisins in Brazilian raw maize samples. Food Control 53: 217-221. DOI:10.1016/j.foodcont.2014.12.038

Oluwafemi F., Kumar M., Bandyopadhyay R., Ogunbanwo T., Ayanwande K. B., 2010. Bio-detoxification of aflatoxin B1 in artificially contaminated maize grains using lactic acid bacteria. Toxin Reviews 29: 3-4. DOI: 10.3109/15569543.2010.512556

Parker N. S., Anderson N. R., Richmond D. S., Long E. Y., Wise K. A., Krupke C. H., 2017. Larval western bean cutworm feeding damage encourages the development of Gibberella ear rot on field corn. Pest Management Science 73: 546-553. DOI:I 10.1002/ps.4313

Parsons M. W., Munkvold G. P., 2012. Effects of planting date and environmental factors on fusarium ear rot symptoms and fumonisin B1 accumulation in maize grown in six North American locations. Plant Pathology 61: 1130-1142.

Paul P. A., El-Allaf S. M., Lipps P. E., Madden L. V., 2004. Rain splash dispersal of Gibberella zeae within wheat canopies in Ohio. Phytopathology 94: 1342.

Picot A., Barreau C., Pinson-Gadais L., Piraux F., Caron D., Lannou C., Richard-Forget F., 2011. The dent stage of maize kernels is the most conducive for fumonisin biosynthesis under field conditions. Applied and Environmental Microbiology 77: 83828390. DOI:10.1128/aem.05216-11 
Pietri A., Zanetti M., Bertuzzi T., 2009. Distribution of aflatoxins and fumonisins in dry-milled maize fractions. Food Additives \& Contaminants Part A, 26: 372-380. DOI:10.1080/02652030802441513

Pitt J. I., Miscamble B. F., 1995. Water relations of Aspergillus flavus and closely related species. Journal of Food Protection 58: 86-90.

Piva G., Battilani P., Pietri A., 2006. Emerging issues in Southern Europe: aflatoxins in Italy. In: The mycotoxin factbook (D. Barug, D. Bhatnagar, H. P. van Egmong, J. W. van der Kamp, W. A. van Osenbruggen, \& A. Visconti, eds), Wageningen Academic Publisher: The Netherlands, 139-153.

Qian G., Tang L., Lin S., Xue K. S., Mitchell N. J., Su J., ... Wang J. S., 2016. Sequential dietary exposure to aflatoxin B1 and fumonisin B1 in F344 rats increases liver preneoplastic changes indicative of a synergistic interaction. Food and Chemical Toxicology 95: 188195. DOI:10.1016/j.fct.2016.07.017

Rasmussen P. H., Nielsen K. F., Ghorbani F., Spliid N. H., Nielsen G. C., Jørgensen L. N., 2012. Occurrence of different trichothecenes and deoxynivalenol-3- $\beta-\mathrm{D}-$ glucoside in naturally and artificially contaminated Danish cereal grains and whole maize plants. Mycotoxin Research 28: 181-190. DOI:10.1007/s12550012-0133-z

Reyneri A., Vanara F., Peila U., Bertetto L., 2004. The distribution of mycotoxins (Fusarium toxins) in products and byproducts of the industrial processing of maize. Tecnica Molitoria 55: 957-966.

Rushing B. R., Selimb M. I., 2019. Aflatoxin B1: A review on metabolism, toxicity, occurrence in food, occupational exposure, and detoxification methods. Food and Chemical Toxicology 124: 81-100. DOI:10.1016/j. fct.2018.11.047

Rychlik M., Humpf H.U., Marko D., Danicke S., Mally A., Berthiller F.H. Lorenz N., 2014. Proposal of a comprehensive definition of modified and other forms of mycotoxins including "masked" mycotoxins. Mycotoxin Research 30:197-205. DOI: 10.1007/s12550014-0203-5

Sahab A. F., Aly S., Hathout A. S., Ziedan E. H., Sabry B. A., 2014. Application of some plant essential oils to control Fusarium isolates associated with freshly harvested maize in Egypt. Journal of Essential Oil Bearing Plants 17: 1146-1155. DOI:10.1080/097206 0x.2014.891447

Samsudin N. P. I., Rodriguez A., Medina A., Magan N., 2017. Efficacy of fungal and bacterial antagonists for controlling growth, FUM1 gene expression and fumonisin B1 production by Fusarium verticillioides on maize cobs of different ripening stages. Inter- national Journal of Food Microbiology 246: 72-79. DOI:10.1016/j.ijfoodmicro.2017.02.004

Savi G. D., Piacentini K. C., Marchi D., Scussel V. M., 2016. Fumonisins B-1 and B-2 in the corn-milling process and corn-based products, and evaluation of estimated daily intake. Food Additives \& Contaminants 33: 339-345. DOI:10.1080/19440049.2015.1124 459

Sawai B., Poonsuk P., Supalak S., 2017. Evaluation of antifungal activity of essential oils against aflatoxigenic Aspergillus flavus and their allelopathic activity from fumigation to protect maize seeds during storage. Industrial Crops and Products 97: 558-566. DOI:10.1016/j.indcrop.2017.01.005

Scala V., Bello C., Fabbri A. A., Fanelli C., Reverberi M., Camera E., Battilani P., 2013. Fusarium verticillioides and maize interaction in vitro: Relationship between oxylipin cross-talk and fumonisin synthesis. World Mycotoxin Journal 6: 343-351. DOI:10.3920/ wmj2013.1527

Scauflaire J., Gourgue M., Callebaut A., Munaut F., 2012. Fusarium temperatum a mycotoxin-producing pathogen of maize. European Journal of Plant Pathology 133: 911-922. DOI:10.1007/s10658-012-9958-8

Schaarschmidt S., Fauhl-Hassek C., 2019. Mycotoxins during the processes of nixtamalization and tortilla production. Toxins 11: 227. DOI: 10.3390/toxins 11040227

Shaner G., 2003. Epidemiology of Fusarium head blight of small grain cereals in North America. In: Fusarium Head Blight of Wheat and Barley (K. J. Leonard, W. Bushnell, eds),(1st ed.), APS Press, St Paul Minnesota US, 84-119.

Shi L., Liang Z., Li J., Hao J., Xu Y., Huang K., ... Xu W., 2014. Ochratoxin A biocontrol and biodegradation by Bacillus subtilis CW 14. Journal of the Science of Food and Agriculture 94: 1879-1885. DOI:10.1002/ jsfa.6507

Sivparsad B. J., Laing M. D., 2016. Pre-harvest silk treatment with Trichoderma harzianum reduces aflatoxin contamination in sweetcorn. Journal of Plant Diseases and Protection 123: 285-293. DOI:10.1007/s41348016-0037-9

Smith J. E., Moss M. O., 1985. Mycotoxins: Formation, Analysis and Significance (J. W. Sons, ed.), Chichester-New York-Brisbane-Toronto-Singapore, pp.

Smith M. C., Madec S., Coton E., Hymery H., 2016. Natural co-occurrence of mycotoxins in foods and feeds and their in vitro combined toxicological effects. Toxins 8: 94. DOI:10.3390/toxins8040094

Stadler D., Lambertini F., Bueschl C., Wiesenberger G., Hametner C., Schwartz-Zimmermann H., ... Krska 
R., 2018. Untargeted LC-MS based ${ }^{13} \mathrm{C}$ labelling provides a full mass balance of deoxynivalenol and its degradation products formed during baking of crackers, biscuits and bread. Food Chemistry. DOI: 10.1016/j.foodchem.2018.11.150

Statista, 2018. European Union-28: maize production volume forecast 2015-2027. Retrieved from https:// www.statista.com/statistics/614393/maize-production-volume-european-union-28/

Streit E., Naehrer K., Rodriguesc I., Schatzmayr G., 2013. Mycotoxin occurrence in feed and feed raw materials worldwide: long-term analysis with special focus on Europe and Asia. Journal of the Science of Food and Agriculture 93: 2892-2899. DOI:10.1002/jsfa.6225

Tayel A. A., El-Tras W. F., Moussa S. H., El-Agamy M. A., 2013. Antifungal action of Pichia anomala against aflatoxigenic Aspergillus flavus and its application as a feed supplement. Journal of the Science of Food and Agriculture 93: 3259-3263. DOI:10.1002/jsfa.6169

Thippeswamy S., Mohana D. C., Abhishek R. U., Manjunath K., 2013. Efficacy of bioactive compounds isolated from Albizia amara and Albizia saman as source of antifungal and antiaflatoxigenic agents. Journal of Consumer Protection and Food Safety 8: 297-305. DOI:10.1007/s00003-013-0839-7

Thippeswamy S., Abhishek R. U., Manjunath K., Raveesha K., Mohana D. C., 2015. Antifumonisin efficacy of 2-Hydroxy-4-Methoxybenzaldehyde isolated from Decalepis hamiltonii. International Journal of Food Properties 18: 2002-2008. DOI:10.1080/10942912.20 14.960930

Torelli E., Firrao G., Bianchi G., Saccardo F., Locci R., 2012. The influence of local factors on the prediction of fumonisin contamination in maize. Journal of the Science of Food and Agriculture 92: 1808-1814. DOI:10.1002/jsfa.5551

Torres O., Matute J., Gelineau-van Waes J., Maddox J. R., Gregory S. G., Ashley-Koch A. E., ... Riley R. T., 2015. Human health implications from co-exposure to aflatoxins and fumonisins in maize based foods in Latin America: Guatemala as a case study. World Mycotoxin Journal 8: 143-159. DOI:10.3920/ WMJ2014.1736

Tracz B. L., Bordin K., Nazareth T., Costa L. B., Freitas M., Renata E., ... Luciano F. B., 2016. Assessment of allyl isothiocyanate as a fumigant to avoid mycotoxin production during corn storage. LWT Food Science and Technology 75: 692-696. DOI:10.1016/j. lwt.2016.10.030

Trenholm H. L., Charmley L. L., Prelusky D. B., Warner R. M., 1991. Two physical methods for the decontamination of four cereals contaminated with deox- ynivalenol and zearalenone Journal of Agricultural and Food Chemistry 39: 356-360. DOI:10.1021/ jf00002a026

van der Fels-Klerx H. J., Camenzuli L., 2016. Effects of milk yield, feed composition, and feed contamination with aflatoxin B1 on the aflatoxin M1 concentration in dairy cows' milk investigated using Monte Carlo simulation modelling. Toxins 8: 290. DOI:10.3390/ toxins 8100290

van der Fels-Klerx H. J., Liu C., Battilani P., 2016. Modelling climate change impacts on mycotoxin contamination. World Mycotoxin Journal 9: 717-726. DOI:10.3920/WMJ2016.2066

Vanara F., Scarpino V., Blandino M., 2018. Fumonisin distribution in maize dry-milling products and byproducts: impact of two industrial degermination systems. Toxins 10: 357. DOI:10.3390/toxins10090357 Verheecke C., Liboz T., Anson P., Zhu Y., Mathieu F., 2016. Streptomyces- Aspergillus flavus interactions: impact on aflatoxin B accumulation. Food Additives and Contaminants 32: 572-576. DOI:10.1080/194400 49.2014.1003336

Xue A. G., Chen Y. H., Sant'anna S. M. R., Voldeng H. D., Fedak G., Savard M. E., ... Harman G. E., 2014. Efficacy of CLO-1 biofungicide in suppressing perithecial production by Gibberella zeae on crop residues. Canadian Journal of Plant Pathology 36: 161-169. DOI:10.1080/07060661.2014.881920

Yaqian L., RuiYan S., Jia Y., Saravanakumar K., Jie C., 2016. Antagonistic and biocontrol potential of Trichoderma asperellum ZJSX5003 against the maize stalk rot pathogen Fusarium graminearum. Indian Journal of Microbiology 56: 318-327. DOI:10.1007/ s12088-016-0581-9

Zachariasova M., Dzuman Z., Veprikova Z., Hajkova K., Jiru M., Vaclavikova M., ... Hajslova J., 2014. Occurrence of multiple mycotoxins in European feeding stuffs, assessment of dietary intake by farm animals. Animal Feed Science and Technology 193: 124-140. DOI:10.1016/j.anifeedsci.2014.02.007 
